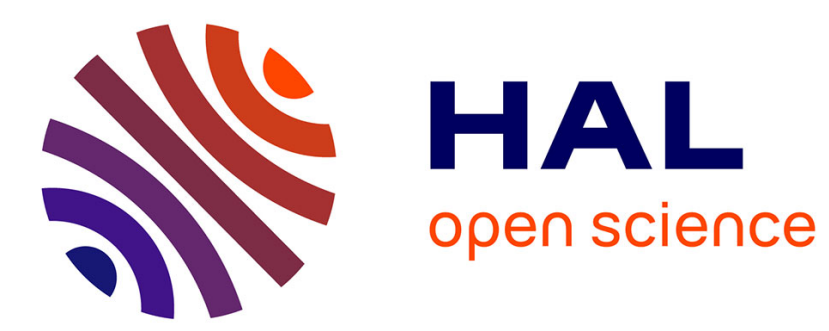

\title{
Are People Willing to Pay for Reduced Inequality?
}

Brian Hill, Thomas Lloyd

\section{To cite this version:}

Brian Hill, Thomas Lloyd. Are People Willing to Pay for Reduced Inequality?. 2021. hal-03503995

\section{HAL Id: hal-03503995 \\ https://hal.science/hal-03503995}

Preprint submitted on 28 Dec 2021

HAL is a multi-disciplinary open access archive for the deposit and dissemination of scientific research documents, whether they are published or not. The documents may come from teaching and research institutions in France or abroad, or from public or private research centers.
L'archive ouverte pluridisciplinaire HAL, est destinée au dépôt et à la diffusion de documents scientifiques de niveau recherche, publiés ou non, émanant des établissements d'enseignement et de recherche français ou étrangers, des laboratoires publics ou privés. 


\title{
Are people willing to pay for reduced inequality? $\|^{k}$
}

\author{
Brian Hil] Thomas Lloyd
}

Novermber 11, 2021

\begin{abstract}
Income inequality is a central issue in current public debate and policy [1-5]. Recent theoretical results have identified the potential of providing consumers with information about the income inequality across those involved in the production of each good at the point of purchase as a tool for mitigating overall inequality [6]. However, its impact depends crucially on whether people are willing to pay more for goods whose production involves less income inequality. Here we investigate this largely unexplored empirical question through incentive-compatible behavioural choice studies on representative samples of the English and US populations. We find that over $80 \%$ of subjects are willing to pay significantly more for goods associated with less extreme inequality. How much more people are willing to pay varies with political leaning and with the extent of the inequality reduction, but is positive across the political spectrum and for all studied inequality differences. Moreover, it is typically higher when inequality is reported in more intuitive and informative formats. Our results suggest the promise of product-level inequality information provision as a tool for moderating income inequality, hinting at impacts even in markets where all goods involve relatively high inequality levels, as well as potential buy-in across the political spectrum.
\end{abstract}

${ }^{*}$ The authors gratefully acknowledge support from a grant of the French National Research Agency (ANR), "Investissements d'Avenir" (LabEx Ecodec/ANR-11-LABX-0047). Personal acknowledgements and thanks to be added.

${ }^{\dagger}$ CNRS \& HEC Paris, GREGHEC, 1 rue de la Libération, 78351 Jouy-en-Josas, France. E-mail: hill@hec.fr. URL: www.hec.fr/hill.

$\ddagger$ University of Michigan, US. E-mail: tmlloyd@umich.edu. 


\section{Contents}

1 Introduction 3

\begin{tabular}{|ll|r}
2 & Results & 5
\end{tabular}

$2.1 \quad$ Are people willing to pay for reduced inequality? . . . . . . . . . . . . 5

2.2 Is WTP sensitive to the extent of inequality reduction?. . . . . . . . . . . . 6

2.3 Is WTP sensitive to the inequality reporting format? . . . . . . . . . . . . . 7

2.4 WTP, political leanings and attitudes $\ldots \ldots \ldots \ldots$. . . . . . . . 8

\begin{tabular}{lll}
\hline 3 & Discussion & 10
\end{tabular}

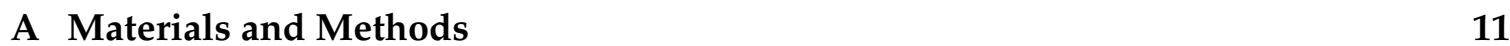

\begin{tabular}{ll}
\hline References & 13
\end{tabular}

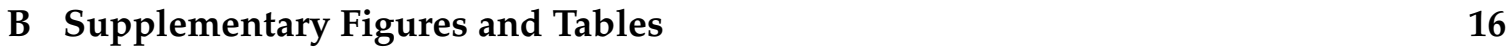

\begin{tabular}{ll}
\hline C Supplementary Information & 27
\end{tabular}

C.1 Supplementary Results . . . . . . . . . . . . . . . . . . . . . . . . . 27

C.1.1 Willingness to pay: descriptive statistics and basic tests . . . . . . . 27

C.1.2 WTP and size of inequality reduction . . . . . . . . . . 28

C.1.3 WTP and Political Leanings . . . . . . . . . . . . . . . . 28

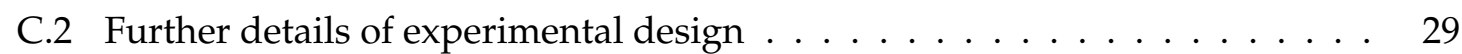




\section{Introduction}

Income inequality is a topic of increasing controversy and relevance [4, 5], which has only been heightened with the Covid-19 crisis. Economics has traditionally concentrated either on understanding income inequality, documenting its extent, evolution and potential causes, or on proposing 'downstream' policies aimed at 'curing' or 'correcting' it, principally through some form of taxation and redistribution [1-3]. Accordingly, studies on public opinion have mainly focused, beyond attitudes to the inequality itself, on the public's attitudes qua citizens to redistribution [7-9]. However, this risks overlooking the power that the public qua consumers could have 'upstream' in 'preventing' income inequality. For consumers who are willing to pay more for goods whose production involves less income inequality, informing them of the inequality associated to each good may impact their purchasing choices, exerting downward market pressure on inequality, even before redistribution. Recent theoretical research makes a case for the potential of blanket inequality reporting at the point of purchase as a policy intervention for moderating inequality $\left.\right|_{1} ^{1}$ showing that it can lead to a reduction in overall income inequality [6]. However, its impact depends crucially on whether consumers are willing to pay for less excessive inequality in the production of the goods they purchase. Are they? How many, and how much? And how does their willingness to pay vary with the extent of the inequality reduction, the format in which inequality information is presented or-given the political divisiveness of inequality-their political leanings?

Motivated by these questions, we investigate willingness to pay (WTP) for reduced inequality across the production of goods through two incentive-compatible, online behavioural choice studies, on representative samples of the English and US populations respectively. Purchasing choices among goods with different inequality levels are seldom investigated in survey studies [11-13] or in the Behavioral Economics literature on inequality attitudes [9, 14-16]. By contrast with established literatures on, say, nutritional information [17, 18], there is a small strand of consumer-oriented research on inequality attitudes [19-21], which this paper complements in four ways. Firstly, few existing studies measure how much more people are willing to pay for goods produced with reduced inequality, focusing instead on stated measures of willingness to buy, for instance. Yet WTP is more relevant for evaluating the potential market consequences of inequality information provision for overall inequality [6]. Secondly, no existing studies on willingness to pay are incentive compatible, in the sense that the mechanism relating subjects' payment to their reported choices makes it in their best interests for their reports to correctly reflect their preferences. Yet, since the effect of inequality information must pass through consumers' purchasing decisions, an incentive-compatible elicitation helps to get closer to actual preferences, mitigating for instance hypothetical or social desirability biases [22, 23]. Thirdly, this is the first experiment, to our knowledge, to elicit WTP for a range of inequality reductions, and compare a variety of inequality reporting formats. Fourthly, this is the first

\footnotetext{
${ }^{1}$ Whilst some information about inequality at the company level is currently available (see for instance [10 and footnote 5), it is not available for all products, and rarely provided at the point of purchase.
} 
behavioural study on country-level representative samples. In both England and the US, income inequality has recently been an important and hotly debated topic in the public sphere $\left.\right|^{2}$ though people in these countries are on average more accommodating of income inequality, compared to other developed countries $3^{3}$

Participants ( $n=270$ for England, $n=540$ for the US) in our study were faced with a shopping situation in which they had a budget of $£ 50$ (for English subjects, $\$ 65$ for US subjects) to spend on towel sets.4 They made a series of binary choices between towel sets that were comparable in all respects except for price and income inequality across the employees of the companies producing them, which were indicated. For a benchmark (very high) inequality level inequ $_{B}$ and (low) price $B=£ 30$ ( $\$ 40$ in the US study), and each of three lower inequality levels $i n e q u_{n}<$ inequ $_{B}$ (Table 1), we elicited the price price ${ }_{n}$ such that the subject is indifferent between paying price $_{B}$ for the towel set with inequality $i n e q u_{B}$ and paying price $_{n}$ for the towel set with inequality inequ $u_{n}$. The WTP for the reduction in inequality from $i n e q u_{B}$ to $i n e q u_{n}$ is the difference price $_{n}-$ price $_{B}$. (If price $_{n}<$ price $_{B}$, which was a possible response, the WTP is negative.) Each price was elicited using a 'staircase' or 'bisection' sequence of straight-out binary choices (Section C.2), a task which is closer to real-life purchasing contexts than Multiple Price Lists, buying or selling prices, or willingness-to-buy reports on a Likert scale. We employed a Random Incentive Mechanism based on those standard in Behavioral Economics. Several subjects were randomly chosen and had one of their choices played 'for real': they were sent a towel set for which the price and the inequality in the company producing it corresponded approximately to those of the good they had selected in the choice, as well as their change from the allocated budget. Subjects were informed at the outset that each had an equal chance of playing a purchase question for real, but were given no information on how that question was selected (Section A. For subjects who are only interested in maximising their cash payout, as well as subjects who are not willing to pay more for goods with reduced inequality across production, the procedure yields an elicited WTP indistinguishable from 0 .

To investigate the impact of inequality reporting format on WTP, we explored four formats (Table 1). All participants' WTP were elicited under the CEO-to-median-worker pay ratio (CEO-MW): the ratio of the company's CEO pay to its median pay across the workforce. This is by far the most commonly used measure of company-level inequality both in practice-with recent regulations in several countries requiring publicly-listed companies to disclose this ratid $5^{5}$ and in the existing empirical literature on attitudes to CEO

\footnotetext{
${ }^{2}$ For instance, inequality is a central theme of the Biden administration (e.g. forbes.com) and of the Deaton review set up by the UK Institute for Fiscal Studies (ifs.co.uk).

${ }^{3}$ For example, in the ISSP 2009 data |13| on participants' ideal CEO-to-unskilled worker pay ratio (how much a CEO should earn / how much an unskilled worker should earn), the US ( $M d n=6.7$, interquartile range $[3.3,17.5])$ has a higher median ratio than Europe $(M d n=4$, interquartile range $[2.5,6.7])$, with the UK $(M d n=5.3$, interquartile range $[3,10.4])$ lying between the two.

${ }^{4}$ Under the exchange rate on the launch date of the US study, $£ 50$ is worth $\$ 66.72$. This sum, like most, roughly corresponds across the studies (see Section A).

${ }^{5}$ Following the adoption, by the SEC, of the Dodd-Frank Act provision requiring publicly traded firms to disclose their CEO-to-median worker pay ratios, US companies started publishing this data in their proxy statements from 2018 onwards (see sec.gov). Similar obligations are present in the UK(gov . uk) and France (economie.gouv).
} 


\begin{tabular}{lcccc}
\hline \hline & $\begin{array}{c}\text { CEO-to-Median } \\
\text { (CEO-MW) }\end{array}$ & $\begin{array}{c}\text { Gini Index } \\
(\mathbf{G I})\end{array}$ & $\begin{array}{c}\text { Inequality scale } \\
\text { (IS) }\end{array}$ & $\begin{array}{c}\text { CEO: Min Wage; } \\
\text { Median: Min Wage } \\
\text { (2D) }\end{array}$ \\
\hline Very High $\left(\right.$ inequ $\left._{B}\right)$ & $750: 1$ & 0.55 & $\mathrm{E}$ & $300: 1 ; 1: 3$ \\
High $\left(\right.$ inequ $\left._{H}\right)$ & $250: 1$ & 0.45 & $\mathrm{D}$ & $30: 1 ; 1: 3$ \\
Medium $\left(\right.$ inequ $\left._{M}\right)$ & $50: 1$ & 0.25 & $\mathrm{~B}$ & $300: 1 ; 3: 1$ \\
Low $\left(\right.$ inequ $\left._{L}\right)$ & $5: 1$ & 0.15 & $\mathrm{~A}$ & $30: 1 ; 3: 1$ \\
\hline \# Subjects (England) & 270 & 102 & 95 & 73 \\
\# Subjects (US) & 540 & 183 & 194 & 163 \\
\hline \hline
\end{tabular}

Table 1: Summary of reporting formats and inequality levels used in the experiment

pay [20, 21]. Each participant's WTP was also elicited for one of three alternative inequality reporting formats. The Gini index (GI)—a real number between 0 (perfect equality) and 1 (a single individual receives all the income) - is one of the most common inequality measures in the economic literature, and is standardly used for country-level inequality [24, 25], though company-level GI data is much rarer ${ }^{6}$. The Inequality score (IS) is a 5-point scale from A (lowest inequality) to $\mathrm{E}$ (highest inequality), of the sort frequently used for information provision concerning energy efficiency [26], nutritional quality [17] or environmental footprint [27]. The 2-dimensional measure (2D) comprises of two ratios-the ratio of the company's CEO pay to the country's minimum wage, and the ratio of the company's median worker pay to the minimum wage-and, though more informative, can typically be computed from the same company-level data needed to calculate the CEO-MW ratio. Participants' WTP were elicited for three reductions-from the very high 'benchmark' inequality level to three lower levels (Table 1) —with levels calibrated across formats, so they correspond to approximately equivalent amounts of inequality (Appendix A). Note that whilst for the one-dimensional formats there is a clear ordering of the inequality levels, in the 2D format only the highest and lowest inequality levels used in the experiment can be unequivocally ordered with respect to the others according to inequality.

\section{Results}

\subsection{Are people willing to pay for reduced inequality?}

As indicated by Figure 1, and confirmed by Figure B.1, both mean and median willingness to pay for reduced inequality are significantly higher than zero across inequality reductions, inequality reporting formats and countries. For the largest inequality reduction and the CEO-MW format, median WTP is $£ 10$ or over in both England and the US, that is to say a third of the price of the very high inequality good ( $£ 30 / \$ 40)$. For all reporting formats and across both countries, one-sample two-sided $t$-tests reject the null hypothesis of zero WTP for the largest inequality reduction ( $p<0.001$ in all cases; Table B.1b), and two-sided binomial tests reject the null hypothesis of equal distribution of strictly positive vs. negative or zero WTP for all inequality reductions ( $p<0.001$ in all cases; Table B.1a). In both

\footnotetext{
${ }^{6}$ Whilst calculating the CEO-MW requires two data points- the CEO salary and the median salary-the GI in principle requires pay information for all employees.
} 


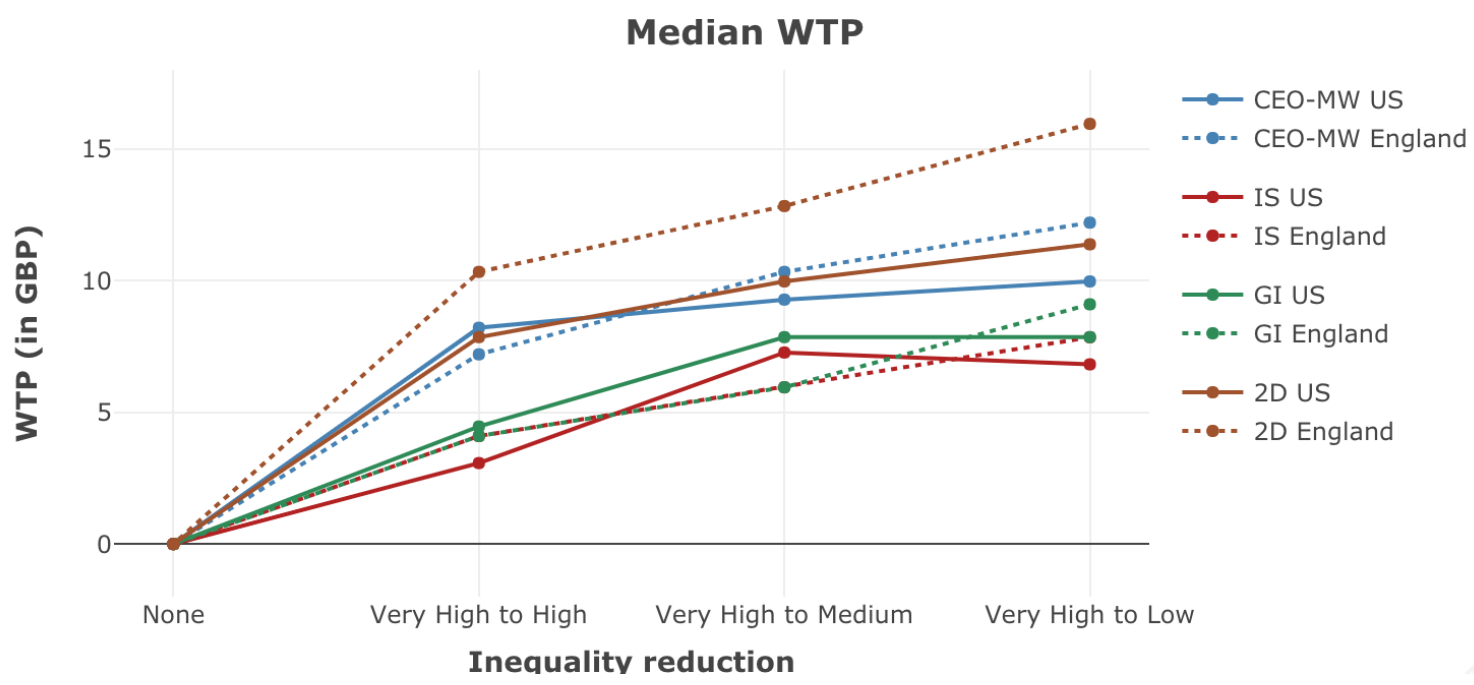

Figure 1: Median WTP in $£$ for various inequality reductions, across reporting formats (Table 1)

England and the US, the proportion of subjects with positive WTP is above $80 \%$ for all inequality reductions under the CEO-MW format, falling to just under $70 \%$ for the lowest inequality reduction under the IS format. Only 10\% of all subjects (29 out of 270 in England, 51 out of 540 in US) exhibited zero WTP across all levels of inequality reduction and reporting formats. Recall that our procedure permitted negative WTP (i.e. people willing to pay more for the more unequal good); as is clear in Figure B.1. some subjects gave such responses 7

To check whether these results depend on the effects of subject income on the perception of the towel set (and its price), we repeated the tests in three income categories, and obtained similar results. Figure B.2 gives violin plots of the WTP for various inequality reductions under CEO-MW across different income brackets.

Given our motivation in terms of information provision, we check how our results are impacted by the extent to which participants would use inequality information if provided. During end-of-experiment survey questions, $67 \%$ of English subjects and $60 \%$ of US ones stated that they would definitely or probably use company-level inequality data when shopping (Table B.9a). The tests for positive WTP under the CEO-MW format continue to hold if all other subjects' WTP was set to zero. Note also that the theoretical effectiveness of inequality information provision does not depend on all consumers having positive WTP, but only on a non-negligible sub-population [6].

\subsection{Is WTP sensitive to the extent of inequality reduction?}

Figure 1 suggests a general sensitivity of the WTP to the extent of inequality reduction. This is confirmed by one-way ANOVAs with repeated measures of WTP against reduction in inequality, which reject the null hypothesis of identical WTP across inequality reduc-

\footnotetext{
${ }^{7} 1 \%$ of all subjects ( 2 out of 270 in England, 7 out of 540 in US) exhibited strictly negative WTP across all levels of inequality reduction and reporting formats.
} 
tions for all inequality formats and both countries ( $p<0.001$ in most cases; Table C.3). Friedman tests come to the same conclusion ( $p<0.001$ in all cases).

Regression analysis, reported in Table B.2, shows that the correlation between WTP and the extent of inequality reduction is generally positive, both across inequality formats and countries. Nevertheless, there are interesting cross-country differences. Whereas among English subjects, WTP increases with each increase in the extent of inequality reduction for the CEO-MW, GI and IS formats $\left.\right|^{8}$ for US subjects, WTP is larger for a reduction to the medium inequality level as compared to a reduction to the high level (Table 1), but there is little evidence of a further increase in WTP when moving to the low inequality level. This could be related to the inequality levels people consider as potentially justified on grounds such as merit, desert or fairness: fewer US subjects willing to pay more for a further inequality reduction may be indicative of a tendency to consider larger inequality levels, e.g. the medium level in Table 1, as acceptable, as compared to English subjects.

Reductions to intermediate inequality levels in the $2 \mathrm{D}$ format involve reductions in upand down-side inequality respectively (Table 1). Since the levels are comparable in absolute terms $9^{9}$ our data can speak to the question of the comparative sensitivity of WTP to inequalities driven by excessively low pay at the bottom of the distribution vs. excessively high pay at the top. Two-sided paired $t$-tests in both countries and Wilcoxon signed-rank tests in the case of the US weakly reject the null hypothesis of equal WTP across the intermediate inequality levels ( $p<0.05$ in all these cases), with more subjects displaying higher WTP for the reduction in down-side inequality as opposed to up-side inequality (Table C.4). There is thus a weak suggestion of higher average willingness to pay for an improvement in the wage of the median worker than for a comparable decrease in inequality coming via a salary reduction at the top.

\subsection{Is WTP sensitive to the inequality reporting format?}

Figure 1 suggests systemic differences in WTP across inequality reporting formats. This is confirmed by split-plot ANOVAs, with the WTP for the largest inequality reduction as the dependent variable, the CEO-MW v.s. treatment format the within factor, and the treatment format the between factor, which find a statistically significant main effect for the within factor (CEO-MW vs. the others) and its interaction with the between factor (IS vs. GI vs. 2D format), in both England and the US (Table B.3a. Two-factor repeatedmeasures ANOVAs comparing the CEO-MW format to the IS and GI formats respectively across levels of inequality reduction come to similar conclusions (Table B.3a). Moreover, two-sided paired $t$-tests and Wilcoxon signed-rank tests, conducted for each reduction in inequality, reject the null hypothesis of equal WTP between CEO-MW and both the IS and GI formats for most levels of inequality reduction and across both countries, with more

\footnotetext{
${ }^{8}$ As noted in the Introduction, the intermediate 2D inequality levels are not unequivocally ordered by inequality.

${ }^{9}$ The (absolute) CEO-to-MW ratio can be calculated from the 2D inequality report (Section A, and indeed, is slightly larger for the down-side inequality improvement (i.e. 300:1; 3:1, corresponding to CEO-MW of 100:1) than for the up-side inequality improvement (i.e. 30:1; 1:3, corresponding to CEO-MW of 90:1).
} 
subjects having higher WTP under CEO-MW than the contrary (Table B.3). Our data thus points to higher WTP under CEO-MW format as compared to both IS and GI. By contrast, in the comparison between CEO-MW and the 2D format, the tests fail to reject the null hypothesis of identical WTP for the largest inequality reduction ${ }^{10}$ for US subjects; in the English cohort, the null hypothesis is weakly rejected by a $t$-test, with more subjects having higher WTP under the 2D format.

Assuming proper calibration of inequality levels (Appendix C.2), the observed differences in WTP across formats may be related to underlying differences in their apprehension by subjects. In particular, the CEO-to-median worker pay ratio is arguably simpler, more intuitive, easier to understand and more meaningful (to non-experts) than the Inequality score and the Gini index; subjects' more 'tenuous connection' with the reports in these latter formats could be driving their lower WTP. This explanation is coherent with subject feedback: across both England and the US, most subjects report the CEO-MW format to be more informative, easier to understand and preferred to both IS and GI (Table B.9b).

\subsection{WTP, political leanings and attitudes}

Figure 2 clearly indicates that willingness to pay is strictly positive across the political spectrum. This is confirmed by two-sided paired $t$-tests, which reject the null hypothesis of zero WTP under the CEO-MW format for all amounts of inequality reduction and every self-reported position as concerns economic policy on the left/right spectrum $(p<0.001$ in all cases; see Table B.4). Wilcoxon signed-rank tests yield similar results. This finding also holds across all reported political parties in both countries, as well as across votes in the 2020 Presidential election in the US (Table B.4). Although we concentrate here on the benchmark CEO-MW format, for which there are more observations, similar results hold for the other inequality reporting formats (Table C.5.

Figure 2 also suggests that, whilst positive across the board, WTP varies with political leanings. This is confirmed by one-way ANOVAs, rejecting the null hypothesis of constant WTP across political leanings $(F(2,267)=6.86, p=0.001$ for England; $F(2,537)=11.02$, $p<0.001$ for the US). Regressions of WTP against political leaning and the size of the inequality reduction (Table B.5) find that, in both countries, the WTP among the cohort with Right political leanings is significantly lower than for those in the Centre, though no significant difference was detected between the Centre and the Left. Moreover, they suggest that sensitivity of WTP to the extent of inequality reduction varies across political leanings. WTP increases with the extent of inequality reduction, at least in certain ranges, among those in the Centre; the increase is more pronounced on the Left; it is less pronounced, bordering on non-existent, on the Right. Separate WTP-against-inequalityreduction regression analyses for each political leaning confirm that, by contrast with the Left and Centre cohorts, no significant general increase in WTP across the inequality re-

\footnotetext{
${ }^{10}$ As noted above, the two intermediate inequality levels under 2D are not unequivocally ordered by inequality, which hinders any comparison of these levels with the CEO-MW format.
} 


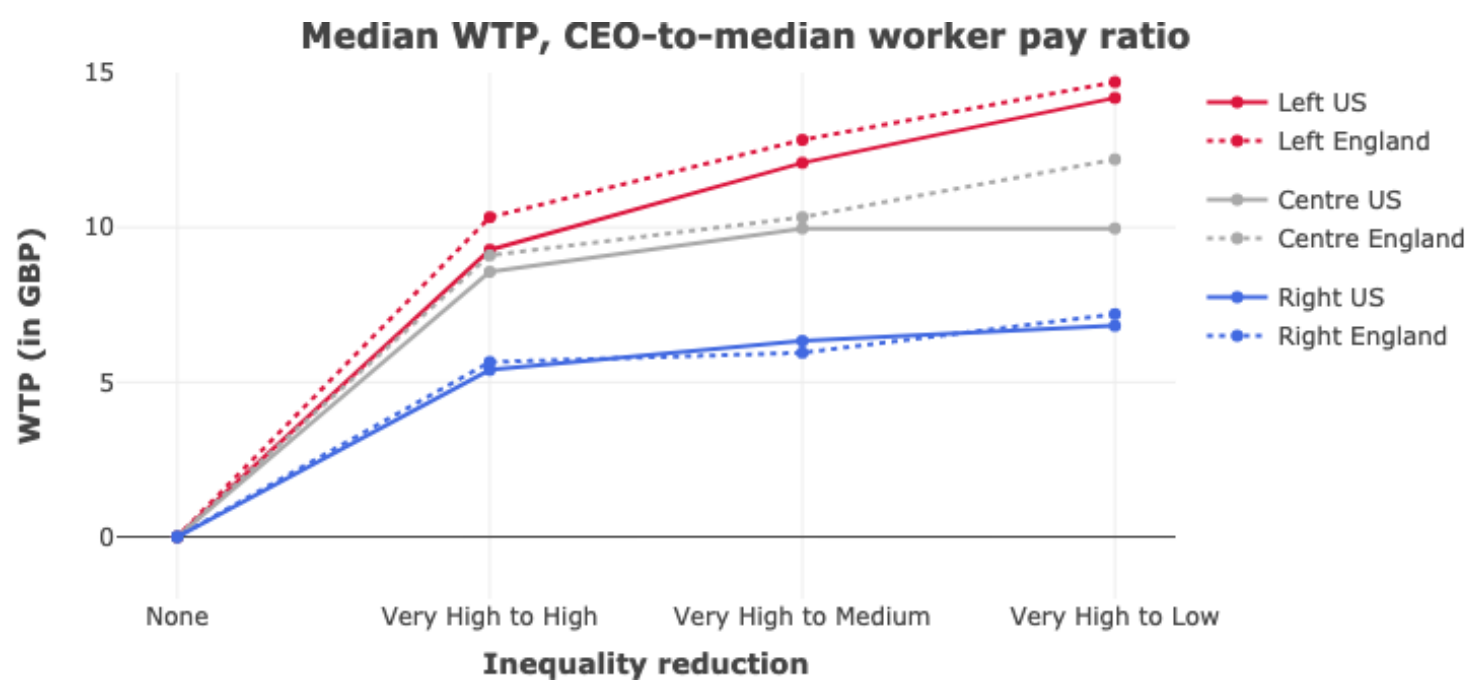

Figure 2: Median WTP in $£$, over self-reported political leanings (CEO-MW format).

ductions explored here is found among those on the Right. Similar patterns hold for the comparison between sympathisers of the two main political parties in each country and across voters for the two main candidates in the 2020 US Presidential Election (Table B.2).

Delving further, regressions of the subjects' average WTP against their self-reported inequality attitudes finds that, in both countries, WTP is significantly impacted by peoples' opinions on the size of income inequality, with WTP increasing with agreement that income differences in the home country are too large (Table B.6). Interestingly, regressions of the WTP against both attitudes to the size of inequality and those to government responsibility for reducing income inequality find a significant effect of the former but not of the latter, and $F$-tests fail to reject the null hypothesis of no impact of attitude to government responsibility on WTP (Table B.6). This suggests that, whilst opinions about the excessiveness of current income inequality may be related to both positive attitudes to government intervention to reduce them and willingness to pay for reduced inequality in purchased goods, the impact of these opinions on WTP is largely independent of attitudes to government action.

Finally, regressions incorporating a range of socio-demographic factors, as well as political leanings, attitudes to the size of income inequality and the extent of inequality reduction point to gender and attitudes to the size of income inequality as the strongest determinants of WTP, both in terms of effect size and significance (Table B.7). The higher WTP found in females is consistent with existing research suggesting that women are more socially oriented than men [28, 29]. Attitudes to the size of inequality usurp the significance of the impact of political leanings whenever present in the regression, suggesting that they are a driving factor behind the effect of political leanings on WTP. We fail to find evidence for significant differences in WTP between England and the US. 


\section{Discussion}

Providing consumers with information about the income inequality involved in the production of goods has been shown to be a potential tool for moderating income inequality [6]. However, its impact will hinge on peoples' willingness to pay for reduced inequality in production. Our finding of widespread positive WTP —often ranging to over a third of the benchmark price-bodes well for the effectiveness of such an intervention. Importantly, it transpires under the incentivisation standards prevalent in Behavioral Economics: by exhibiting positive WTP, subjects potentially sacrifice actual cash payment for a lower inequality good. Moreover, WTP is positive not only for large inequality reductions but also for smaller ones, from an inequality level that, though very high, is typical in the top $10 \%$ of most-unequal firms (Table C.7). This suggests that, even in markets where all goods involve relatively high levels of inequality, information provision may still have an impact.

Beyond the headline result, our other findings further comfort the promise of information provision. First of all, while WTP varies across the political spectrum-consistent with findings that concern for inequality is related to political leanings [8]-it is positive across the board, including on the right and among those close to traditional centre-right political parties. Moreover, our data indicates that WTP is related to opinions concerning the size of income inequality, and that this relation is largely independent of attitudes to government intervention. This suggests that 'upstream' policies passing through attitudes to consumption of high-inequality goods-and in particular information provision-may have broader buy-in than 'downstream' policies, such as redistribution. For instance, whilst surveys typically find that $40 \%$ of the UK population support government redistribution, $80 \%$ consider income inequality to be too large [30, 31]. Finally, around two-thirds of subjects stated they would definitely or probably use inequality information when shopping if it was provided, again boding well for the proposed intervention.

Our findings may also be relevant for practical challenges facing the implementation of information provision. One proposal for delivering inequality information to consumers in a convenient format at the point of purchase uses a mobile phone application [6]. This poses the question of which inequality format to report: whilst there is a rich literature on inequality measures [32-34], little has focused on their usefulness for communicating product-level inequality to consumers with no specialist knowledge or theoretical baggage. Our results suggest that, for all its weaknesses as a comprehensive inequality measure, the CEO-to-median worker pay ratio fairs better on this front than the more sophisticated Gini Index and the simpler Inequality score. It is considered more informative and easier to understand by most subjects, is preferred to the alternatives and induces higher WTP. This may be because it strikes a balance between informativeness and understandability, 'connecting' better with subjects whilst clearly singling out an objective, informative and conceptually simple dimension of inequality. 


\section{A Materials and Methods}

The studies were pre-registered on the Open Science platform (https://osf.io/vsk 39 for the English study, and https://osf . io/ehr53 for the US one). The English online choice experiment was conducted in May 2020 with $n=270$ participants, the US one between late November 2020 and mid-January 2021 with $n=540$ participants, both recruited through Qualtrics (an online panel provider). Each sample was representative of the over18 population of the respective country, in terms of age, gender and region (Table B.8). The experiments were identical bar the translation of choice questions into the home currency and one survey question (vote in the 2020 US Presidential Election; see Table C.10).

We used a mixed design. Subjects having read the instructions and answered correctly a set of comprehension questions concerning them were randomly assigned to one of three treatment groups. Each group undertook two blocks of elicitation tasks: one for the CEOMW format, and the other for a treatment-dependent alternative inequality reporting format (see Table 1 for the formats and the number of subjects per group). At the beginning of each block the inequality format used was explained, and subjects had two attempts to complete a comprehension question concerning it before proceeding. Each block involved the elicitation of three WTPs, each of which was the reduction in inequality from a benchmark very high inequality level, with a towel set priced at $£ 30 / \$ 4011$ to a lower inequality level (Tables 1 and C.6). The inequality levels used were set based on available CEO-median wage ratio data in the US and UK and calibrated, as far as possible, across reporting formats (Appendix C.2). The order of blocks was randomised for each subject, as was the order of elicitations within each block. After completing these tasks, subjects answered feedback and survey questions, detailed in Table C.10.

Participants were presented with situations in which they are shopping online for towels, and have a budget of $£ 50$ / \$65. Each choice question involved two suitable offers for a 6-piece white cotton towel set from two different, anonymous online home retailers. For each towel set, they were only told the price and an indication of the inequality level among employees of the company producing and selling the product and asked to choose the towel set they wished to buy. We elicit WTP via such questions using a version of the 'bisection' or 'staircase' method [35-37]. More specifically, for the benchmark price and inequality level $\left(\right.$ price $_{B}$, inequ $_{B}$ ) and a inequality level inequ $u_{n}$, we elicit the indifference point-the price price $_{n}$ such that the subject is indifferent between a towel set with price $_{B}$, inequ $_{B}$ ) and one with $\left(\right.$ price $_{n}$, inequ $u_{n}$ - -through a chained sequence of binary-choice questions between a towel set with fixed inequality and price $\left(\right.$ price $_{B}$, inequ $\left._{B}\right)$ and towel sets with $\left(\right.$ price $_{i}$, inequ $\left._{n}\right)$, where the inequality remains fixed and the price varies across questions. The WTP for the reduction in inequality from $i n e q u_{B}$ to $i n e q u_{n}$ is price $_{n}-$ price $_{B}$. The procedure was designed so that the first two binary choices in each sequence, for price $_{i}$ $=£ 30, £ 40(\$ 40, \$ 50)$, were the same for all participants.

Beyond the standard participation fee, we implemented a random incentive mecha-

\footnotetext{
${ }^{11}$ The US price points were designed to approximately match the English ones, under the exchange rate on the first day of the US study (24 November, 2020).
} 
nism to ensure incentive compatibility. At the beginning of the experiment, participants were informed that they each had an equal chance of being selected to receive the budget and have one of their purchasing decisions automatically selected by the program and played for real. 'Playing for real' involved, on the one hand, the participant being sent a towel set that is sold at the price and by a company whose inequality across the workforce is as specified in the option they chose in the selected purchasing decision. On the other hand, they were sent, as change, the difference between the budget and the price of the towel set they chose. After data collection, randomly chosen subjects were remunerated according to their choice in the same question, namely that between a towel set with inequality 750:1 on the CEO-MW scale and price $£ 30$ / $\$ 40$, and a towel set with inequality $5: 1$ and price $£ 40 / \$ 50$. As noted previously, by the experimental design, all subjects faced this question. (Table C.9 contains details on the products used for remuneration.)

This random incentive mechanism ensured that subjects were in complete ignorance about the purchasing decision that would be played for real if they were selected; it was thus in their best interest to answer truthfully in each binary choice they faced ${ }^{12}$ It did so whilst allowing us to remunerate according to the same choice for all subjects. This was key to tackling the central challenge for incentive-compatible elicitation in this context, namely the difficulty in finding products whose inequality in production and price match those in the choice questions faced by subjects. For each reporting format, the cohort could face over 20 different prices for each of three different inequality levels-and it is practically impossible to find, for each price and inequality level, a company with that level of inequality selling a good of a fixed type at that price. Moreover, for certain formats, such as GI, publishable data on with-company inequality is unavailable.

\footnotetext{
${ }^{12}$ Specifically, given their ignorance, they could not rule out any of the choices as being possibly played for real, and hence their weakly dominant strategy was to answer truthfully.
} 


\section{References}

[1] Piketty, T. Capital in the Twenty-First Century (Harvard University Press, 2014).

[2] Acemoglu, D. \& Autor, D. in Handbook of Labor Economics 1043-1171 (Elsevier, 2011).

[3] Atkinson, A. B., Piketty, T. \& Saez, E. Top incomes in the long run of history. Journal of Economic Literature 49, 3-71 (2011).

[4] World Economic Forum. Global Risks 2014, Ninth Edition http : / / www3 . we forum. org/docs/WEF_GlobalRisks_Report_2014.pdf. Accessed the 22 July 2020. 2014.

[5] Deaton, A. Republic of unequals. Prospect Magazine. https://www. prospectmagazine. co.uk/opinions/us-inequality-wealth-divide(Jan. 2021).

[6] Hill, B. Being up front about Income Inequality. HEC Paris Research Paper No. ECO/SCD2020-1362. http://dx.doi.org/10.2139/ssrn.3515349 (2020).

[7] Orton, M., Rowlingson, K., et al. Public attitudes to economic inequality (Joseph Rowntree Foundation York, 2007).

[8] Kuziemko, I., Norton, M. I., Saez, E. \& Stantcheva, S. How elastic are preferences for redistribution? Evidence from randomized survey experiments. American Economic Review 105, 1478-1508 (2015).

[9] Almäs, I., Cappelen, A. W. \& Tungodden, B. Cutthroat Capitalism versus Cuddly Socialism: Are Americans More Meritocratic and Efficiency-Seeking than Scandinavians? Journal of Political Economy 128 (2020).

[10] AFL-CIO. Company Pay Ratios https : / / aflcio . org / paywatch / companypay-ratios. Accessed the 25 March 2020. 2020.

[11] Osberg, L. \& Smeeding, T. "Fair" inequality? Attitudes toward pay differentials: the United States in comparative perspective. American sociological review 71, 450-473 (2006).

[12] Kiatpongsan, S. \& Norton, M. I. How much (more) should CEOs make? A universal desire for more equal pay. Perspectives on Psychological Science 9, 587-593 (2014).

[13] ISSP Research Group. International Social Survey Programme: Social Inequality IV - ISSP 2009 GESIS Data Archive, Cologne. ZA5400 Data file Version 4.0.0. https : / / doi . org/10.4232/1.12777, 2017.

[14] Fehr, E. \& Schmidt, K. M. The economics of fairness, reciprocity and altruism-experimental evidence and new theories. Handbook of the economics of giving, altruism and reciprocity 1, 615-691 (2006).

[15] Camerer, C. F. \& Fehr, E. When does "economic man" dominate social behavior? Science 311, 47-52 (2006).

[16] Clark, A. E. \& d'Ambrosio, C. in Handbook of income distribution 1147-1208 (Elsevier, 2015). 
[17] Julia, C., Etilé, F. \& Hercberg, S. Front-of-pack Nutri-Score labelling in France: an evidence-based policy. Lancet Public Health 3, e164 (2018).

[18] Dubois, P. et al. Effects of front-of-pack labels on the nutritional quality of supermarket food purchases: evidence from a large-scale randomized controlled trial. Journal of the Academy of Marketing Science 49, 119-138 (2021).

[19] Mohan, B., Norton, M. I. \& Deshpandé, R. Paying up for fair pay: Consumers prefer firms with lower CEO-to-worker pay ratios. Harvard Business School Marketing Unit Working Paper (2015).

[20] Benedetti, A. H. \& Chen, S. High CEO-to-worker pay ratios negatively impact consumer and employee perceptions of companies. Journal of Experimental Social Psychology 79, 378-393 (2018).

[21] Mohan, B., Schlager, T., Deshpandé, R. \& Norton, M. I. Consumers Avoid Buying From Firms With Higher CEO-to-Worker Pay Ratios. Journal of Consumer Psychology 28, 344-352 (2018).

[22] Harrison, G. W. \& Rutström, E. E. Experimental evidence on the existence of hypothetical bias in value elicitation methods. Handbook of experimental economics results $\mathbf{1}$, 752-767 (2008).

[23] Krumpal, I. Determinants of social desirability bias in sensitive surveys: a literature review. Quality \& Quantity 47, 2025-2047 (2013).

[24] Cingano, F. Trends in income inequality and its impact on economic growth tech. rep. (OECD, 2014).

[25] OECD. Income inequality https://www.oecd-ilibrary.org/content/data/ 459aa7f1-en, 2020.

[26] European Union Energy label and ecodesign https : / / ec . europa . eu / info/ energy-climate-change-environment/standards-tools-and-labels/ products-labelling-rules-and-requirements/energy-label-andecodesign_en. 2020.

[27] Ceci-Renaud, N \& Tarayoun, T. Comportements d'achat en présence d'affichage environnemental: les enseignements d'une enquête par expériences de choix. Ministère de L'environnement: Paris, France (2016).

[28] Eckel, C. C. \& Grossman, P. J. Are women less selfish than men?: Evidence from dictator experiments. The economic journal 108, 726-735 (1998).

[29] Andreoni, J. \& Vesterlund, L. Which is the fair sex? Gender differences in altruism. The Quarterly Journal of Economics 116, 293-312 (2001).

[30] Curtice, J., Clery, E., Perry, J., Phillips, M. \& Rahim, N. British social attitudes 36 www . bsa.natcen.ac.uk (London, 2019).

[31] Clery, E., Curtice, J. \& Harding, R. British social attitudes 34 www . bsa . natcen . ac . uk (London, 2017). 
[32] Lambert, P. The Distribution and Redistribution of Income: Third Edition 338 pp. (Manchester University Press, 2001).

[33] Chakravarty, S. R. Inequality, polarization and poverty (Springer, New York, 2009).

[34] Cowell, F. Measuring inequality (Oxford University Press, 2011).

[35] Cornsweet, T. N. The staircase-method in psychophysics. The American journal of psychology 75, 485-491 (1962).

[36] Bostic, R., Herrnstein, R. J. \& Luce, R. D. The Effect on the Preference-Reversal Phenomenon of Using Choice Indifferences. Journal of Economic Behavior E Organization 13, 193-212 (Mar. 1990).

[37] Falk, A. et al. Global evidence on economic preferences. The Quarterly Journal of Economics 133. Publisher: Oxford University Press, 1645-1692 (2018).

[38] Office for National Statistics. Census 2011 Data https://www . nomisweb.co.uk/ census/2011/key_statistics. 2013.

[39] CIPD. Executive pay in the FTSE 100 - Is everyone getting a fair slice of the cake? https: //www.cipd.co.uk/Images/ftse-100-executive-pay-report-2019_ tcm18-62886.pdf. Accessed the 17 June 2020. 2020.

[40] World Bank. GINI index (World Bank estimate) https : / / data.worldbank .org/ indicator/SI.POV.GINI. Accessed the 27 April 2020. 2020.

[41] Morais, F. \& Kakabadse, N. K. The Corporate Gini Index (CGI) determinants and advantages: Lessons from a multinational retail company case study. International Journal of Disclosure and Governance 11, 380-397 (2014). 


\section{B Supplementary Figures and Tables}
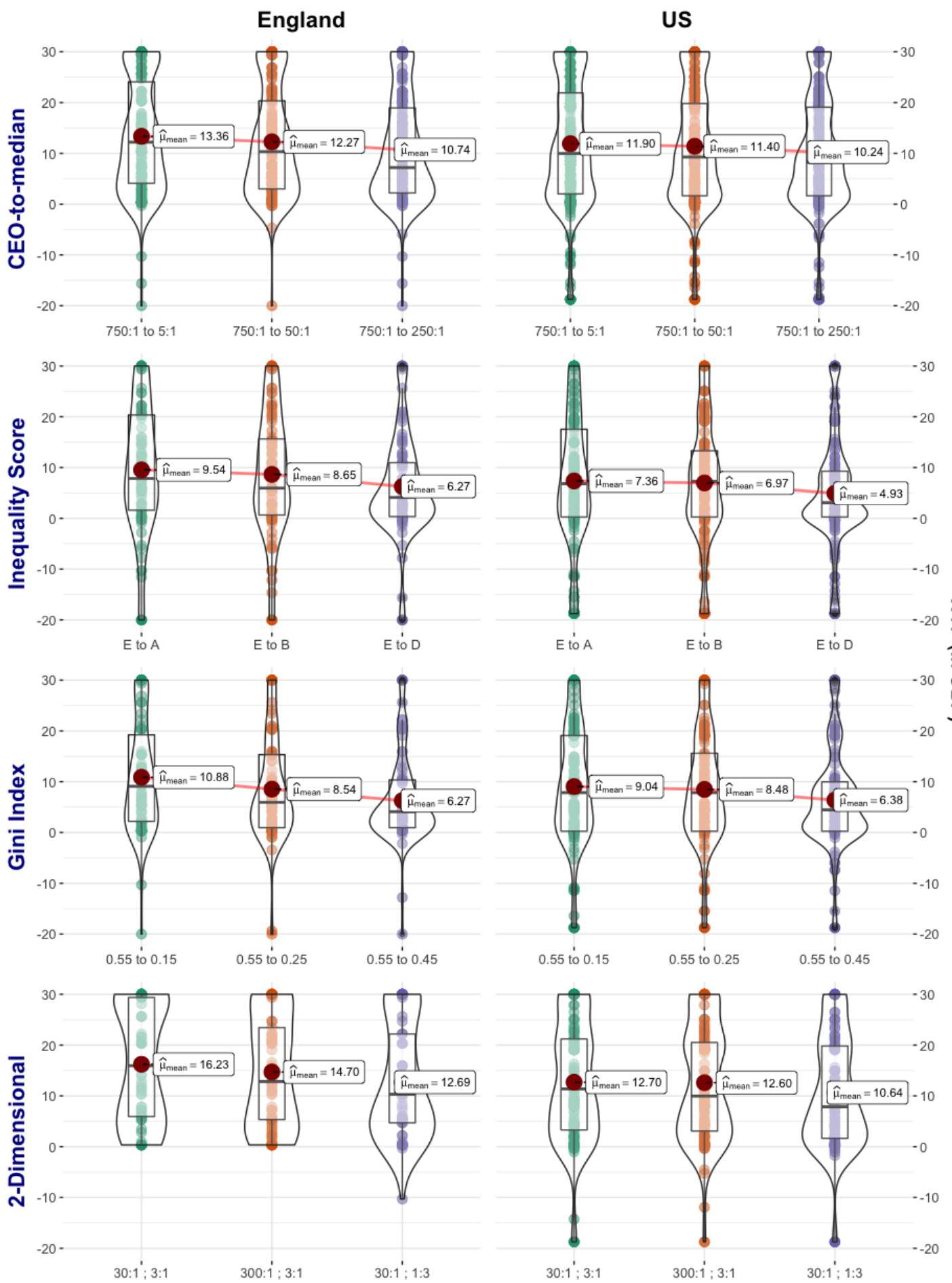

Inequality Reduction (from highest level)

Figure B.1: WTP in $£$ for inequality reductions from very high inequality level $i n e q u_{B}$ at price of $£ 30$, for each inequality format.

Here and throughout, when results are given in pounds, dollar values are converted using the exchange rate on the first day of the US study (24 November, 2020), $£ 1=\$ 1.3343$. 


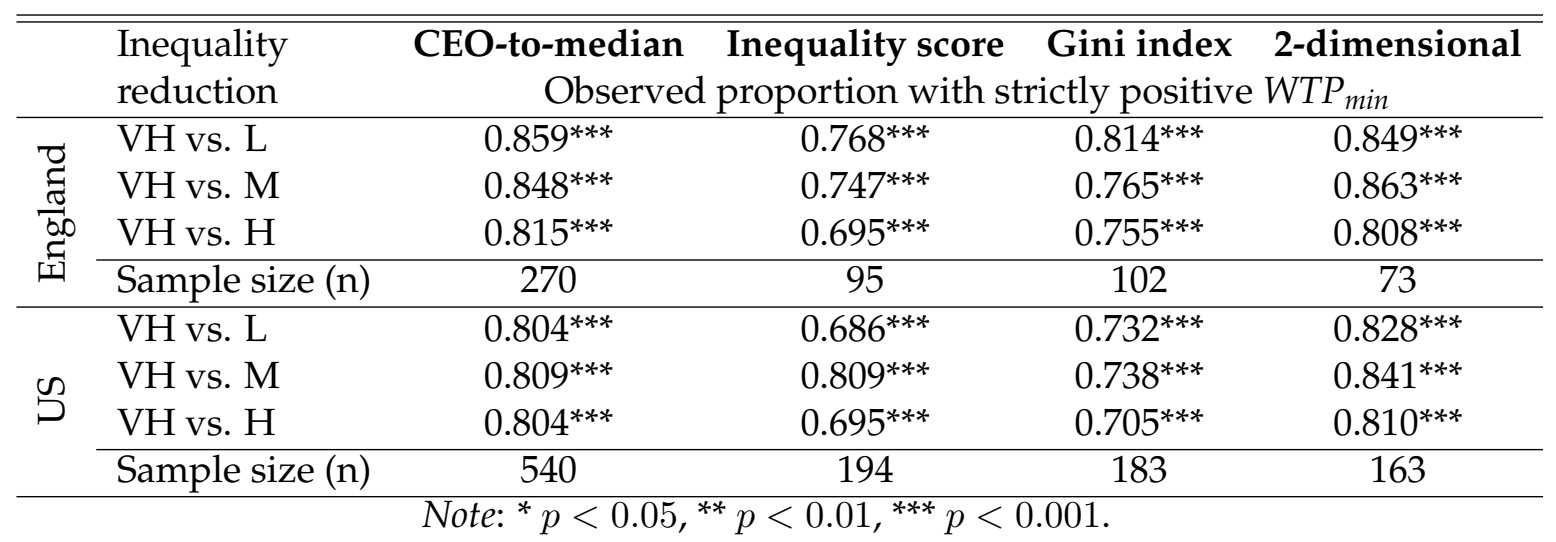

(a) Proportion of subjects with strictly positive $W T P_{\min }$ and one-sided Binomial tests of the null hypothesis that the probability of strictly positive $W T P_{\min }$ is 0.5 , across reporting formats and levels of reduced inequality. (Recall from Section C.2 that we can say for sure that an individual's WTP is positive whenever the lowest WTP coherent with her choices, $W T P_{\min }$, is positive.)

\begin{tabular}{|c|c|c|c|c|c|}
\hline & & CEO-to-median & Inequality score & Gini index & 2-dimensional \\
\hline \multirow{5}{*}{ 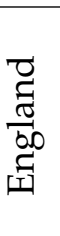 } & WTP & $13.36^{* * *}$ & $9.54^{* * *}$ & $10.88^{* * *}$ & $16.23^{* * *}$ \\
\hline & $($ in $£)$ & $(0.668)$ & $(1.31)$ & (1.06) & $(1.34)$ \\
\hline & $W T P_{\min }$ & $13.05^{* * *}$ & $9.24^{* * *}$ & $10.58^{* * *}$ & $15.95^{* * *}$ \\
\hline & $(i n £)$ & $(0.670)$ & $(1.31)$ & (1.06) & (1.35) \\
\hline & Sample size (n) & 270 & 95 & 102 & 73 \\
\hline \multirow{5}{*}{ ص } & WTP & $15.88^{* * *}$ & $9.82^{* * *}$ & $12.07^{* * *}$ & $16.94^{* * *}$ \\
\hline & (in \$) & $(0.694)$ & $(1.23)$ & $(1.13)$ & $(1.22)$ \\
\hline & $W T P_{\text {min }}$ & $15.50^{* * *}$ & $9.4^{* * *}$ & $11.69^{* * *}$ & $16.58^{* * *}$ \\
\hline & (in \$) & $(0.694)$ & $(1.22)$ & (1.13) & $(1.22)$ \\
\hline & Sample size (n) & 540 & 194 & 183 & 163 \\
\hline
\end{tabular}

(b) Mean values of WTP and $W T P_{\min }$ for the largest reduction in inequality, and one-sample (twosided) $\mathrm{t}$-tests of the null hypothesis that $W T P$ (respectively $W T P_{\min }$ ) equals 0.

Table B.1: Binomial and t-tests for positive WTP. Wilcoxon signed-rank tests give similar results. 

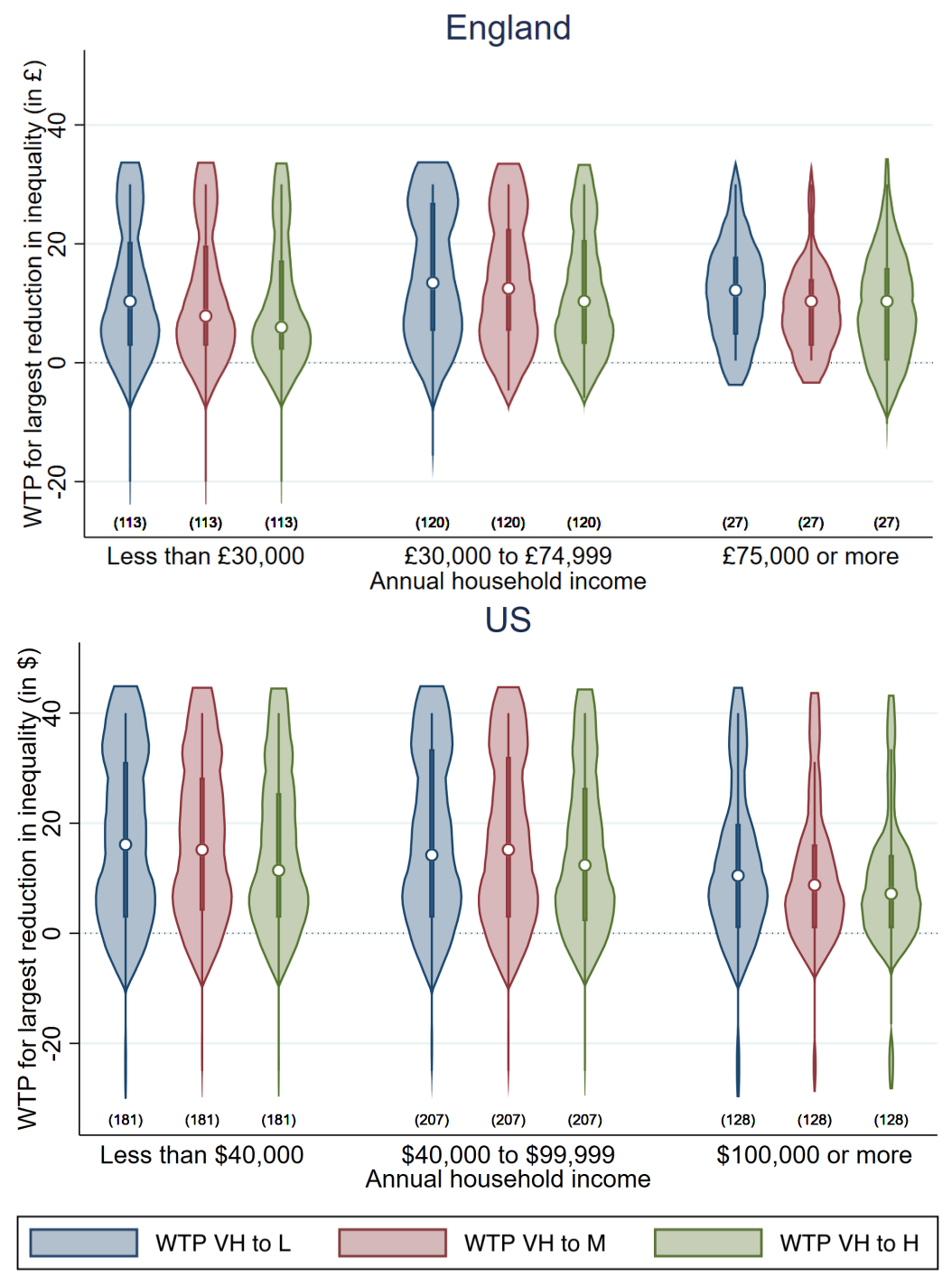

Figure B.2: Distribution of WTP for the each reduction in inequality under CEO-MW format over three income categories (using Epanechnikov kernel function). One-sample two-sided $t$-tests reject the null hypothesis of zero WTP for all inequality reductions and income categories, in both countries $(p<0.001$ in all cases).

(For comparison the median self-reported pre-tax household income among our subjects was in the 130,000 $£ 39,999$ bracket in England and in the $\$ 50000-\$ 75000$ bracket in the US, and the median disposable household income in the fiscal year ending in 2019 was $£ 29,600$ in the UK (gov . uk) and $\$ 68703$ in the US (census . gov).) 


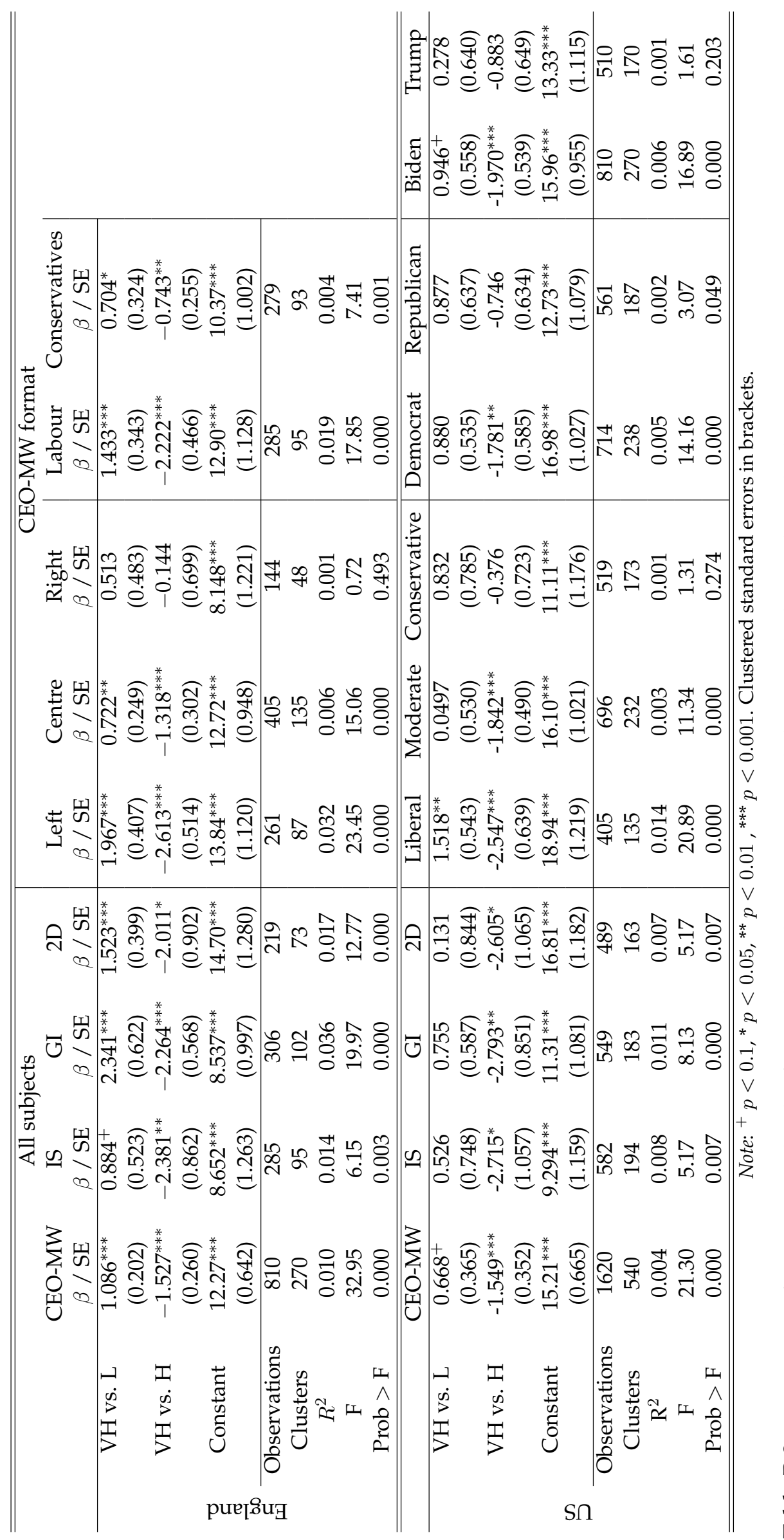

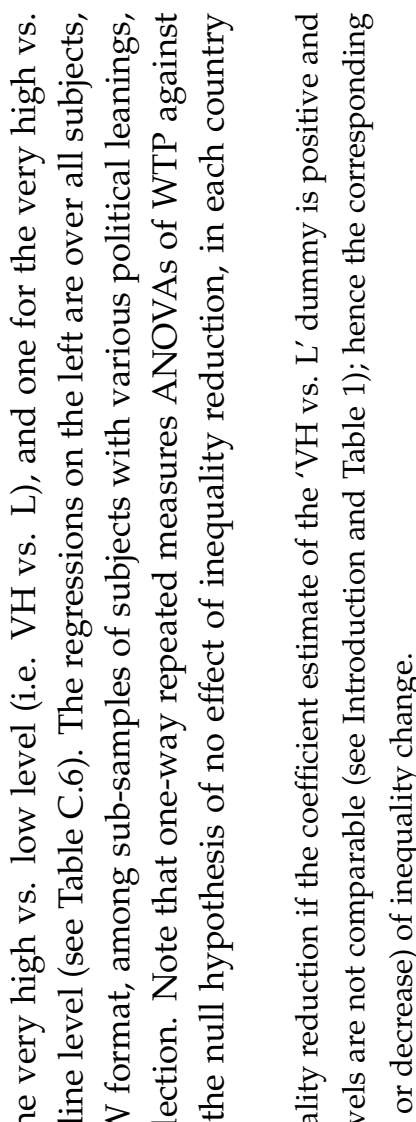

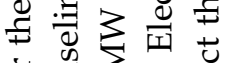

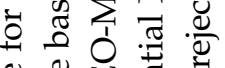
\&

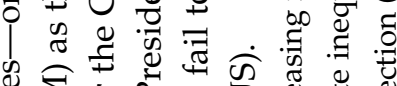

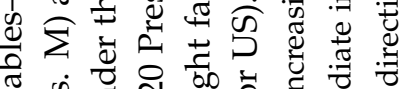

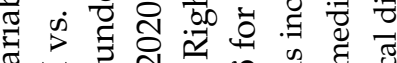

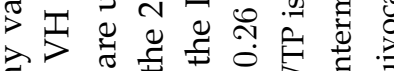

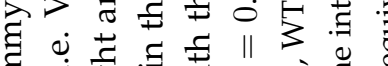

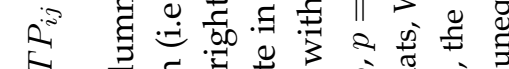

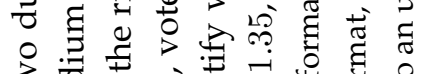
उ

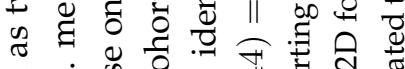

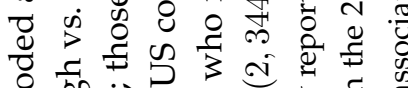

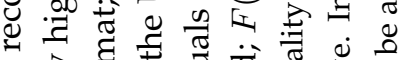
.

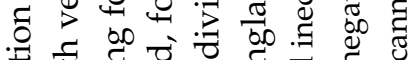

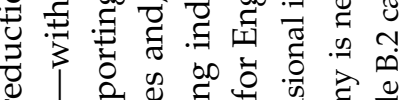

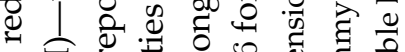

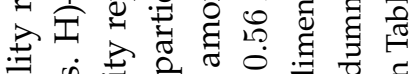

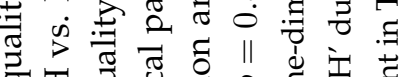

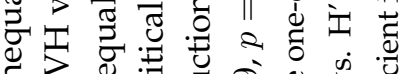

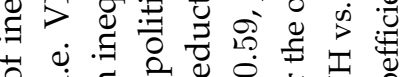
虫.

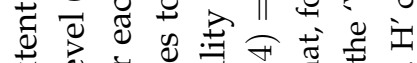

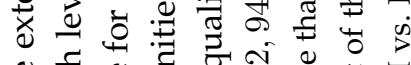

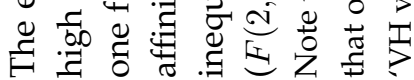




\begin{tabular}{llccccc}
\hline \hline ANOVA & Factor & $d f$ & $d f_{\text {residual }}$ & $F$ & $p$ & $\eta_{p}^{2}$ \\
\hline \multirow{2}{*}{ Split-plot } & CEO-Tr & 1 & 267 & 6.29 & 0.013 & 0.02 \\
England & Tr & 2 & 267 & 3.63 & 0.028 & 0.03 \\
& CEO-Tr $\times$ Tr & 2 & 267 & 12.15 & 0.000 & 0.08 \\
\hline \multirow{2}{*}{ Split-plot } & CEO-Tr & 1 & 537 & 22.08 & 0.000 & 0.04 \\
US & Tr & 2 & 537 & 3.06 & 0.048 & 0.01 \\
& CEO-Tr $\times$ Tr & 2 & 537 & 11.89 & 0.000 & 0.04 \\
\hline \hline \multirow{2}{*}{ IS } & Format & 1 & 94 & 18.35 & 0.000 & 0.16 \\
England & Redn & 2 & 188 & 19.29 & 0.000 & 0.17 \\
& Format $\times$ Redn & 2 & 188 & 0.96 & 0.372 & 0.01 \\
\hline \multirow{2}{*}{ IS } & Format & 1 & 193 & 45.11 & 0.000 & 0.19 \\
US & Redn & 2 & 386 & 11.09 & 0.000 & 0.05 \\
& Format $\times$ Redn & 2 & 286 & 0.72 & 0.481 & 0.00 \\
\hline \hline \multirow{2}{*}{ GI } & Format & 1 & 101 & 21.25 & 0.000 & 0.17 \\
England & Redn & 2 & 202 & 40.71 & 0.000 & 0.29 \\
& Format $\times$ Redn & 2 & 202 & 4.52 & 0.015 & 0.04 \\
\hline \multirow{2}{*}{ GI } & Format & 1 & 182 & 15.59 & 0.000 & 0.08 \\
\multirow{2}{*}{ US } & Redn & 2 & 364 & 13.02 & 0.000 & 0.07 \\
& Format $\times$ Redn & 2 & 364 & 2.32 & 0.102 & 0.01 \\
\hline \hline
\end{tabular}

(a) The split-plot ANOVA has the WTP for the largest inequality reduction as the dependent variable, the CEO-MW v.s. treatment format the within factor (CEO-Tr), and the treatment format (Tr) the between factor. For each of IS and GI, the table reports two-factor repeated measures ANOVAs, where WTP is the dependent variable, the factors are the format (i.e. CEO-MW vs. treatment format) and the extent of inequality reduction (Redn).

\begin{tabular}{|c|c|c|c|c|c|c|c|c|c|c|c|c|}
\hline \multirow{3}{*}{\multicolumn{2}{|c|}{$\begin{array}{l}\text { Inequality } \\
\text { reduction }\end{array}$}} & \multicolumn{11}{|c|}{ WTP: CEO-MW vs. IS } \\
\hline & & \multicolumn{4}{|c|}{$t$-test } & \multicolumn{3}{|c|}{ Wilcoxon } & \multicolumn{4}{|c|}{ \# CEO-MW } \\
\hline & & $d f$ & $t$ & $p$ & $d_{z}$ & $z$ & $p$ & $r$ & Higher & Equal & Lower & Total \\
\hline \multirow{3}{*}{ 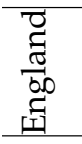 } & VH vs. L & 94 & 3.97 & 0.000 & 0.41 & 4.47 & 0.000 & 0.46 & 49 & 34 & 12 & 95 \\
\hline & VH vs. M & 94 & 3.21 & 0.002 & 0.33 & 3.45 & 0.001 & 0.35 & 45 & 32 & 18 & 95 \\
\hline & VH vs. H & 94 & 4.85 & 0.000 & 0.50 & 5.33 & 0.000 & 0.55 & 52 & 28 & 15 & 95 \\
\hline \multirow{6}{*}{$s$} & VH vs. L & 193 & 5.60 & 0.000 & 0.40 & 6.31 & 0.000 & 0.45 & 99 & 68 & 27 & 194 \\
\hline & VH vs. M & 193 & 5.35 & 0.000 & 0.38 & 6.00 & 0.000 & 0.43 & 91 & 74 & 29 & 194 \\
\hline & VH vs. H & 193 & 6.64 & 0.000 & 0.48 & 7.66 & 0.000 & 0.55 & 110 & 61 & 23 & 194 \\
\hline & & \multicolumn{11}{|c|}{ "WTP: CEO-MW vs. GI } \\
\hline & & \multicolumn{4}{|c|}{$t$-test } & \multicolumn{3}{|c|}{ Wilcoxon } & \multicolumn{4}{|c|}{ \# CEO-MW } \\
\hline & & $d f$ & $t$ & $p$ & $d_{z}$ & $z$ & $p$ & $r$ & Higher & Equal & Lower & Total \\
\hline \multirow{4}{*}{ 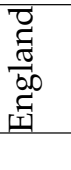 } & VH vs. L & 101 & 1.50 & 0.136 & 0.15 & 2.13 & 0.034 & 0.21 & 39 & 44 & 19 & 102 \\
\hline & VH vs. M & 101 & 3.89 & 0.000 & 0.39 & 3.64 & 0.000 & 0.36 & 45 & 37 & 20 & 102 \\
\hline & VH vs. $\mathrm{H}$ & 101 & 4.08 & 0.000 & 0.40 & 5.17 & 0.000 & 0.51 & 56 & 31 & 15 & 102 \\
\hline & VH vs. L & 182 & 2.30 & 0.023 & 0.17 & 3.04 & 0.002 & 0.22 & 75 & 68 & 40 & 183 \\
\hline \multirow{5}{*}{ מ } & VH vs. M & 182 & 2.87 & 0.005 & 0.21 & 3.77 & 0.000 & 0.28 & 79 & 72 & 32 & 183 \\
\hline & VH vs. $\mathrm{H}$ & 182 & 5.09 & 0.000 & 0.38 & 6.26 & 0.000 & 0.46 & 103 & 56 & 24 & 183 \\
\hline & & \multicolumn{11}{|c|}{ WTP: CEO-MW vs. 2D } \\
\hline & & \multicolumn{4}{|c|}{$t$-test } & \multicolumn{3}{|c|}{ Wilcoxon } & \multicolumn{4}{|c|}{ \# CEO-MW } \\
\hline & & $d f$ & $t$ & $p$ & $d_{z}$ & $z$ & $p$ & $r$ & Higher & Equal & Lower & Total \\
\hline Eng. & VH vs. L & 72 & 2.14 & 0.035 & 0.25 & 2.10 & 0.066 & 0.25 & 103 & 56 & 24 & 183 \\
\hline US & VH vs. L & 162 & 0.86 & 0.391 & 0.07 & 0.86 & 0.484 & 0.07 & 42 & 76 & 45 & 163 \\
\hline
\end{tabular}

(b) Paired tests of equality of WTP across formats (null hypothesis: equal WTP for the specified level across the two considered inequality reduction formats) and number of subjects with WTP under CEO-MW greater than, equal to or less than WTP under other formats, across levels of inequality reduction.

Table B.3: ANOVAs, paired tests and counts across inequality reporting formats. 


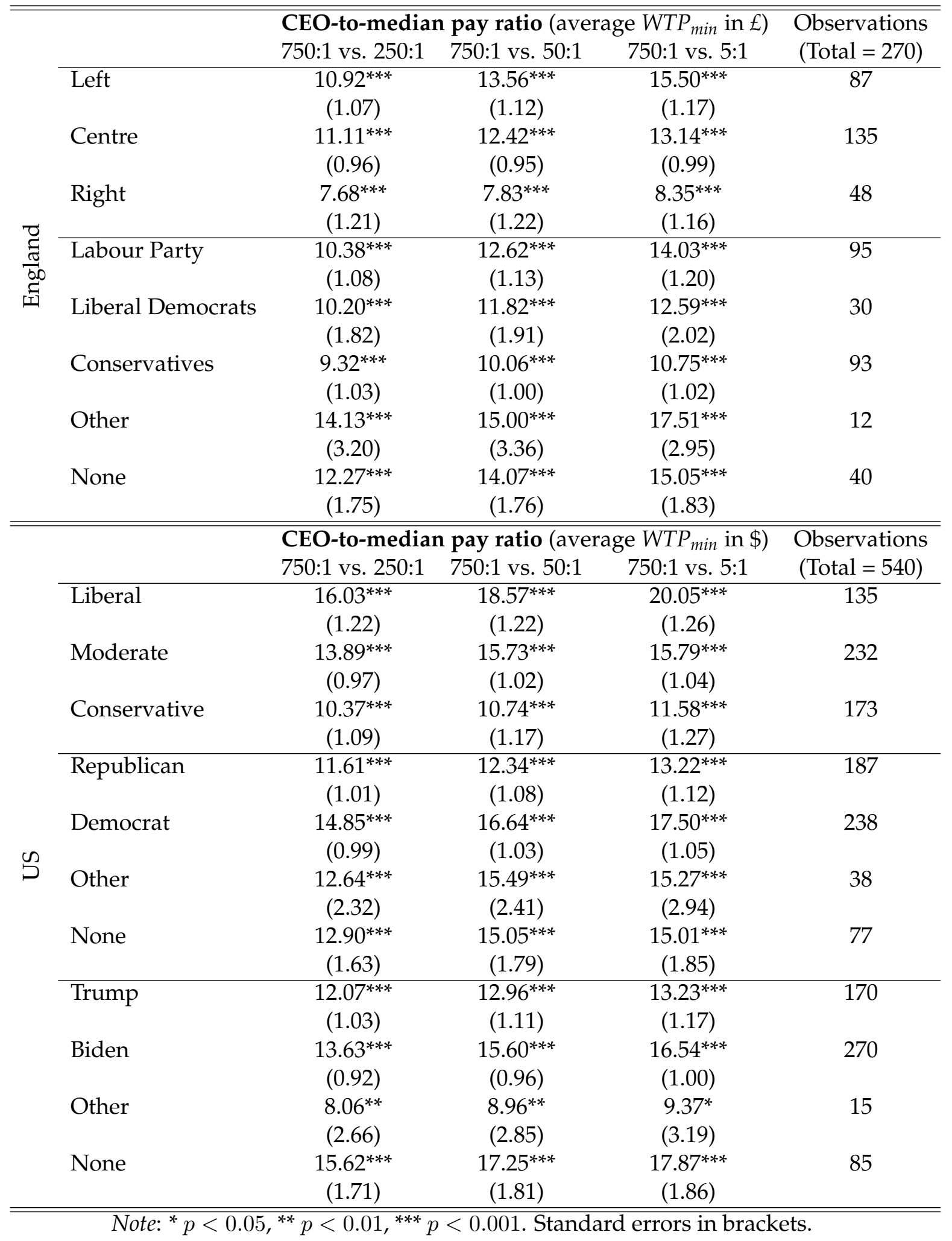

Table B.4: Sample means and one-sample t-tests of $W T P_{\min }$ by political ideology, party affinity, or vote in the 2020 US Presidential Election 


\begin{tabular}{|c|c|c|}
\hline & $\begin{array}{c}\text { England } \\
\beta / \mathrm{SE}\end{array}$ & $\begin{array}{l}\mathrm{US} \\
\beta / \mathrm{SE}\end{array}$ \\
\hline Left & 1.115 & $2.840^{+}$ \\
\hline (Liberal) & (1.466) & $(1.588)$ \\
\hline Right & $-4.576^{* *}$ & $-4.985^{* *}$ \\
\hline (Conservative) & $(1.536)$ & (1.556) \\
\hline VH vs. L & $\begin{array}{c}0.722^{* *} \\
(0.249)\end{array}$ & $\begin{array}{l}0.0497 \\
(0.530)\end{array}$ \\
\hline VH vs. $\mathrm{H}$ & $\begin{array}{c}-1.318^{* * *} \\
(0.302)\end{array}$ & $\begin{array}{c}-1.842^{* * *} \\
(0.490)\end{array}$ \\
\hline Left $\times$ VH vs. L & $\begin{array}{l}1.244^{* *} \\
(0.476)\end{array}$ & $\begin{array}{l}1.468^{+} \\
(0.758)\end{array}$ \\
\hline Left $\times$ VH vs. $H$ & $\begin{array}{c}-1.296^{*} \\
(0.595)\end{array}$ & $\begin{array}{l}-0.705 \\
(0.803)\end{array}$ \\
\hline Right $\times$ VH vs. L & $\begin{array}{l}-0.209 \\
(0.539)\end{array}$ & $\begin{array}{c}0.783 \\
(0.946)\end{array}$ \\
\hline Right $\times$ VH vs. $\mathrm{H}$ & $\begin{array}{c}1.174 \\
(0.754)\end{array}$ & $\begin{array}{l}1.466^{+} \\
(0.873)\end{array}$ \\
\hline Constant & $\begin{array}{c}12.72^{* * *} \\
(0.949)\end{array}$ & $\begin{array}{c}16.10^{* * *} \\
(1.021)\end{array}$ \\
\hline Observations & 810 & 1620 \\
\hline Clusters & 270 & 540 \\
\hline $\mathrm{F}$ & 10.85 & 10.90 \\
\hline Prob $>F$ & 0.000 & 0.000 \\
\hline
\end{tabular}

Table B.5: Pooled OLS regression of WTP (in $£$ for England; in \$ for US) for reduced inequality against political belief and inequality reduction for the CEO-MW format, with clustered Standard Errors.

$$
\begin{aligned}
& \beta_{0}+\beta_{1} \times \mathbb{1}_{\text {Left } i}+\beta_{2} \times \mathbb{1}_{\text {Right } i}+\beta_{3} \times \mathbb{1}_{V H \rightarrow L j}+\beta_{4} \times \mathbb{1}_{V H \rightarrow H j} \\
W T P_{i j}= & +\beta_{5} \times \mathbb{1}_{\text {Left } i} \times \mathbb{1}_{V H \rightarrow L j}+\beta_{6} \times \mathbb{1}_{\text {Left } i} \times \mathbb{1}_{V H \rightarrow H j} \\
& +\beta_{7} \times \mathbb{1}_{\text {Right } i} \times \mathbb{1}_{V H \rightarrow L j}+\beta_{8} \times \mathbb{1}_{\text {Right } i} \times \mathbb{1}_{V H \rightarrow H j}+u_{i j}
\end{aligned}
$$

'Centre' / 'Moderate' is the baseline for political leaning, and 'VH vs. $\mathrm{M}^{\prime}$ is the baseline for the inequality level. Recall (Table B.2) that WTP is increasing in the inequality reduction if the 'VH vs. $\mathrm{L}^{\prime}$ dummy is positive, and the ' $\mathrm{VH}$ vs. $\mathrm{H}^{\prime}$ dummy is negative. 


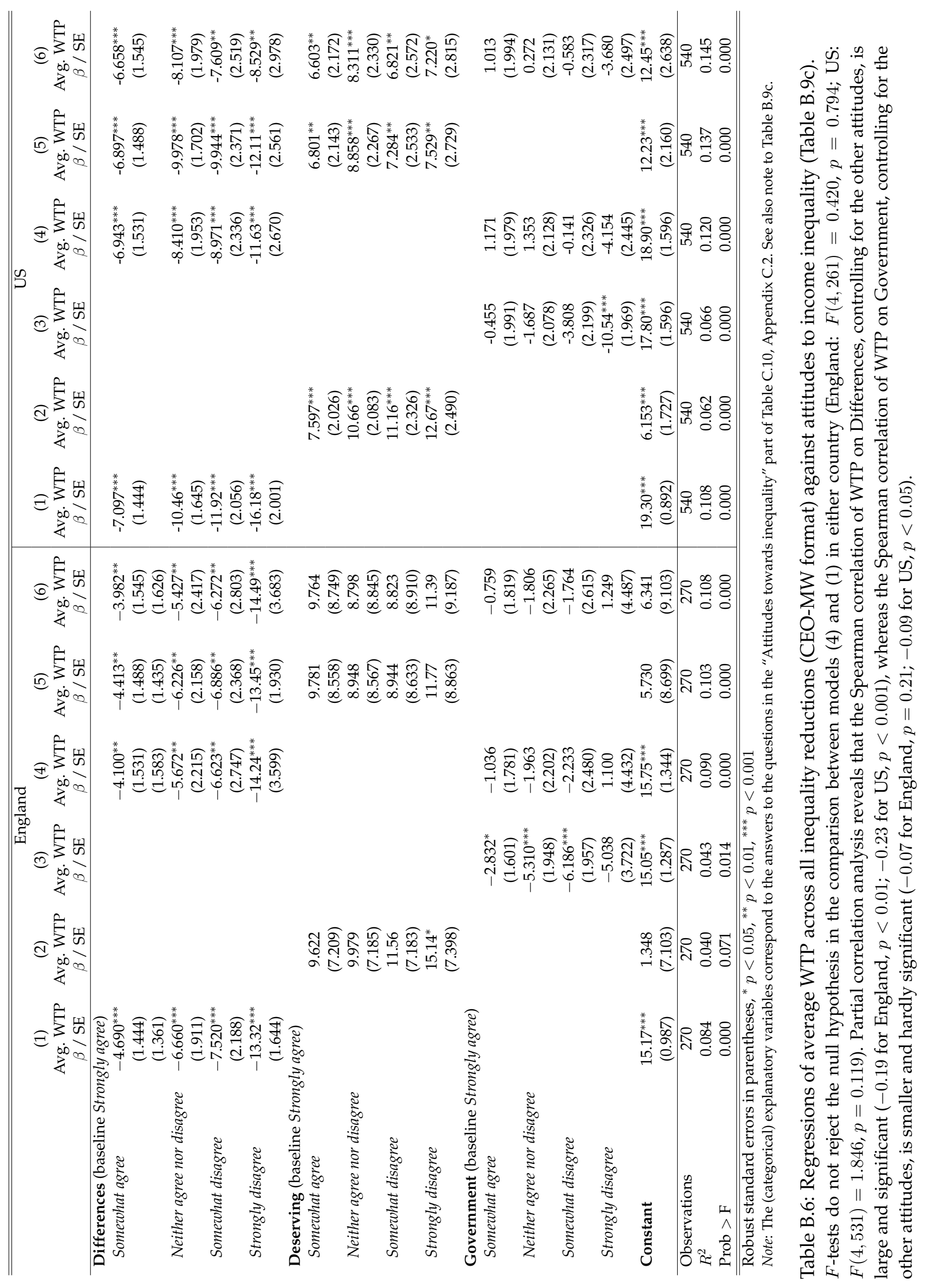




\begin{tabular}{|c|c|c|c|c|}
\hline & $\begin{array}{c}(1) \\
\text { WTP } \\
\beta / \text { SE }\end{array}$ & $\begin{array}{c}(2) \\
\text { WTP } \\
\beta / \text { SE }\end{array}$ & $\begin{array}{c}(3) \\
\text { WTP } \\
\beta / \text { SE }\end{array}$ & $\begin{array}{c}(4) \\
\text { WTP } \\
\beta / \text { SE }\end{array}$ \\
\hline $\begin{array}{l}\text { Country: US } \\
\text { (Baseline England) }\end{array}$ & $\begin{array}{l}-0.72 \\
(0.96)\end{array}$ & $\begin{array}{l}-0.29 \\
(0.94)\end{array}$ & $\begin{array}{l}-0.69 \\
(0.92)\end{array}$ & $\begin{array}{l}-0.69 \\
(0.92)\end{array}$ \\
\hline $\begin{array}{l}\text { Gender: Female } \\
\text { (Baseline Male) }\end{array}$ & $\begin{array}{c}4.95^{* * *} \\
(0.73)\end{array}$ & $\begin{array}{l}4.66^{* * *} \\
(0.72)\end{array}$ & $\begin{array}{l}4.34^{* * *} \\
(0.71)\end{array}$ & $\begin{array}{c}4.34^{* * *} \\
(0.71)\end{array}$ \\
\hline $\begin{array}{l}\text { Age: } 18-34 \\
\text { (Baseline 35-54) }\end{array}$ & $\begin{array}{l}2.10^{*} \\
(0.94)\end{array}$ & $\begin{array}{l}1.47 \\
(0.94)\end{array}$ & $\begin{array}{l}1.04 \\
(0.93)\end{array}$ & $\begin{array}{c}1.04 \\
(0.93)\end{array}$ \\
\hline Age: $55+$ & $\begin{array}{l}1.91^{*} \\
(0.85)\end{array}$ & $\begin{array}{l}2.10^{*} \\
(0.84)\end{array}$ & $\begin{array}{l}1.99^{*} \\
(0.83)\end{array}$ & $\begin{array}{l}1.99^{*} \\
(0.83)\end{array}$ \\
\hline $\begin{array}{l}\text { Income: }<£ 30 \mathrm{k} /<\$ 40 \mathrm{k} \\
\text { (Baseline } £ 30 k-£ 75 k / \$ 40 k-\$ 100 k)\end{array}$ & $\begin{array}{l}-0.87 \\
(0.85)\end{array}$ & $\begin{array}{l}-1.17 \\
(0.84)\end{array}$ & $\begin{array}{l}-1.48 \\
(0.82)\end{array}$ & $\begin{array}{l}-1.48 \\
(0.82)\end{array}$ \\
\hline Income: $\geq £ 75 \mathrm{k} / \geq \$ 100 \mathrm{k}$ & $\begin{array}{c}-3.16^{* *} \\
(0.97)\end{array}$ & $\begin{array}{c}-3.23^{* * *} \\
(0.96)\end{array}$ & $\begin{array}{l}-2.65^{* *} \\
(0.97)\end{array}$ & $\begin{array}{l}-2.65^{* *} \\
(0.97)\end{array}$ \\
\hline $\begin{array}{l}\text { Education: No High School Diploma } \\
\text { (Baseline H.S. Diploma or equivalent) }\end{array}$ & $\begin{array}{l}-0.11 \\
(1.85)\end{array}$ & $\begin{array}{c}0.13 \\
(1.84)\end{array}$ & $\begin{array}{c}0.03 \\
(1.81)\end{array}$ & $\begin{array}{c}0.03 \\
(1.81)\end{array}$ \\
\hline Education: University Degree & $\begin{array}{c}0.11 \\
(1.00)\end{array}$ & $\begin{array}{l}-0.15 \\
(0.97)\end{array}$ & $\begin{array}{c}0.02 \\
(0.96)\end{array}$ & $\begin{array}{c}0.02 \\
(0.97)\end{array}$ \\
\hline $\begin{array}{l}\text { Political leanings: Left } \\
\text { (Baseline Centre) }\end{array}$ & & $\begin{array}{l}1.92^{*} \\
(0.91)\end{array}$ & $\begin{array}{c}0.63 \\
(0.90)\end{array}$ & $\begin{array}{c}0.63 \\
(0.90)\end{array}$ \\
\hline Political leanings: Right & & $\begin{array}{c}-2.93^{* * *} \\
(0.89)\end{array}$ & $\begin{array}{l}-1.70 \\
(0.90)\end{array}$ & $\begin{array}{l}-1.70 \\
(0.90)\end{array}$ \\
\hline $\begin{array}{l}\text { Differences: Somewhat agree } \\
\text { (Baseline Strongly agree) }\end{array}$ & & & $\begin{array}{c}-3.79^{* * *} \\
(0.89)\end{array}$ & $\begin{array}{c}-3.79^{* * *} \\
(0.89)\end{array}$ \\
\hline Differences: Other & & & $\begin{array}{c}-6.91^{* * *} \\
(1.01)\end{array}$ & $\begin{array}{c}-6.91^{* * *} \\
(1.01)\end{array}$ \\
\hline $\begin{array}{l}\text { Inequ Redn: } \mathrm{VH} \text { to } \mathrm{L} \\
\text { (Baseline } V H \text { vs. } M \text { ) }\end{array}$ & & & & $\begin{array}{c}0.68^{* * *} \\
(0.20)\end{array}$ \\
\hline Inequ Redn: $\mathrm{VH}$ to $\mathrm{H}$ & & & & $\begin{array}{l}-1.25^{* * *} \\
(0.20)\end{array}$ \\
\hline Constant & $\begin{array}{c}9.11^{* * *} \\
(1.12)\end{array}$ & $\begin{array}{c}9.55^{* * *} \\
(1.19)\end{array}$ & $\begin{array}{c}12.61^{* * *} \\
(1.24)\end{array}$ & $\begin{array}{c}12.80^{* * *} \\
(1.25)\end{array}$ \\
\hline $\mathrm{R}^{2}$ & 0.075 & 0.099 & 0.147 & 0.152 \\
\hline Adj. $R^{2}$ & 0.072 & 0.095 & 0.142 & 0.147 \\
\hline Prob $>F$ & 0.000 & 0.000 & 0.000 & 0.000 \\
\hline Num. obs. & 2328 & 2328 & 2328 & 2328 \\
\hline Clusters & 776 & 776 & 776 & 776 \\
\hline
\end{tabular}

Standard errors in parentheses, ${ }^{* * *} p<0.001 ;{ }^{* *} p<0.01 ;{ }^{*} p<0.05$. Clustered standard errors in brackets. Note: The explanatory variables correspond to the country of the subject (for Country), the level (for Inequality Reduction), and, for the others, to the answers to the corresponding questions in part of Table C.10 Appendix C.2 The Age, Income, Education and Differences factors have all been grouped into three categories, as specified. In all models, the dependent variable is WTP for a given level of inequality reduction, with one data point per level and subject. 34 subjects were removed since they did not report their income.

Table B.7: Regressions of WTP in $£$, under the CEO-MW format, against demographic factors, attitudes to size of income inequality, and extent of inequality reduction, with clustered Standard Errors. 


\begin{tabular}{lcc|c}
\hline \hline Gender & Freq. & $\%$ & $(\mathrm{C})$ \\
\hline Male & 124 & $45.9 \%$ & $49.2 \%$ \\
Female & 146 & $54.1 \%$ & $50.8 \%$ \\
\hline
\end{tabular}

\begin{tabular}{lcc|c}
\hline \hline Region & Freq. & $\%$ & $(\mathrm{C})$ \\
\hline Northern England & 72 & $26.7 \%$ & $28.2 \%$ \\
Mid England & 85 & $31.5 \%$ & $30.1 \%$ \\
Southern England & 75 & $27.8 \%$ & $26.3 \%$ \\
Greater London & 38 & $14.1 \%$ & $15.4 \%$ \\
\hline
\end{tabular}

\begin{tabular}{lcc|c}
\hline \hline Age & Freq. & $\%$ & $(\mathrm{C})$ \\
\hline $18-24$ & 27 & $10.0 \%$ & $11.9 \%$ \\
$25-34$ & 55 & $20.4 \%$ & $17.2 \%$ \\
$35-44$ & 51 & $18.9 \%$ & $17.8 \%$ \\
$45-54$ & 57 & $21.1 \%$ & $17.5 \%$ \\
$55-64$ & 47 & $17.4 \%$ & $14.8 \%$ \\
$65+$ & 33 & $12.2 \%$ & $20.8 \%$ \\
\hline
\end{tabular}

\begin{tabular}{lcc|c}
\hline \hline Highest Qualification & Freq. & $\%$ & $(\mathrm{C})$ \\
\hline Less than High School & 34 & $12.6 \%$ & $57.8 \%$ \\
High School graduate & 65 & $24.1 \%$ & $13.1 \%$ \\
Post-High School & 171 & $63.3 \%$ & $29.0 \%$ \\
\hline
\end{tabular}

Note: The (C) column corresponds to the actual breakdown of the English population retrieved from 2011 Census data [38].

(a) Distribution of respondents by gender, region, age and highest level of qualification; England

\begin{tabular}{lcc|c}
\hline \hline Gender & Freq. & $\%$ & $(\mathrm{C})$ \\
\hline Male & 260 & $48.2 \%$ & $48.4 \%$ \\
Female & 280 & $51.9 \%$ & $51.6 \%$ \\
\hline
\end{tabular}

\begin{tabular}{lcc|c}
\hline \hline Region & Freq. & $\%$ & $(\mathrm{C})$ \\
\hline Northeast & 102 & $18.9 \%$ & $17.0 \%$ \\
Midwest & 117 & $21.7 \%$ & $20.8 \%$ \\
South & 208 & $38.5 \%$ & $38.3 \%$ \\
West & 113 & $20.9 \%$ & $23.9 \%$ \\
\hline
\end{tabular}

\begin{tabular}{lcc|c}
\hline \hline Age & Freq. & $\%$ & $(\mathrm{C})$ \\
\hline $18-24$ & 58 & $10.7 \%$ & $11.6 \%$ \\
$25-34$ & 100 & $18.5 \%$ & $18.0 \%$ \\
$35-44$ & 87 & $16.1 \%$ & $16.4 \%$ \\
$45-54$ & 87 & $16.1 \%$ & $16.2 \%$ \\
$55-64$ & 93 & $17.2 \%$ & $16.7 \%$ \\
$65+$ & 115 & $21.3 \%$ & $21.1 \%$ \\
\hline
\end{tabular}

\begin{tabular}{lcc|c}
\hline \hline Highest Qualification & Freq. & $\%$ & $(\mathrm{C})$ \\
\hline Less than High School & 11 & $2.0 \%$ & $10.6 \%$ \\
High School graduate & 259 & $48.0 \%$ & $28.3 \%$ \\
Post-High School & 270 & $50.0 \%$ & $61.2 \%$ \\
\hline
\end{tabular}

Note: The (C) column corresponds to the actual breakdown of the US population retrieved from the U.S. Census Bureau, Current Population Survey, Annual Social and Economic Supplement, 2019 (census . gov).

(b) Distribution of respondents by gender, region, age and highest level of qualification; US

\begin{tabular}{l|ccc|r}
\hline \hline & \multicolumn{3}{|c|}{ Political spectrum } & \\
Political Party & Left & Centre & Right & Total \\
\hline Conservatives & 4 & 46 & 43 & 93 \\
Labour Party & 68 & 26 & 1 & 95 \\
Liberal Democrats & 7 & 23 & 0 & 30 \\
Other & 4 & 8 & 0 & 12 \\
None & 4 & 32 & 4 & 40 \\
\hline Total & 87 & 135 & 48 & 270 \\
\hline
\end{tabular}

(c) Distribution of respondents by political leanings and affinities, England

\begin{tabular}{|c|c|c|c|c|}
\hline \multirow[b]{2}{*}{ Political Party } & \multicolumn{3}{|c|}{ Political spectrum } & \multirow[b]{2}{*}{ Total } \\
\hline & Liberal & Moderate & Conservative & \\
\hline Republicans & 10 & 45 & 132 & 187 \\
\hline Democrats & 116 & 101 & 21 & 238 \\
\hline Other & 5 & 25 & 8 & 38 \\
\hline None & 4 & 61 & 12 & 77 \\
\hline Total & 135 & 232 & 173 & 540 \\
\hline
\end{tabular}

(d) Distribution of respondents by political leanings and affinities, US

Table B.8: Socio-demographic and political breakdown of subject pool. 


\begin{tabular}{lcc|cc}
\hline \hline & \multicolumn{3}{c}{ Stated future use } \\
& \multicolumn{2}{c}{ England } & \multicolumn{2}{c}{ US } \\
& $\mathrm{n}$ & $\%$ & $\mathrm{n}$ & $\%$ \\
\hline Definitely yes & 78 & $28.9 \%$ & 148 & $27.4 \%$ \\
Probably yes & 104 & $38.5 \%$ & 175 & $32.4 \%$ \\
Might or might not & 50 & $18.5 \%$ & 125 & $23.2 \%$ \\
Probably not & 30 & $11.1 \%$ & 69 & $12.8 \%$ \\
Definitely not & 8 & $3.0 \%$ & 23 & $4.3 \%$ \\
\hline Total & 270 & $100 \%$ & 540 & $100 \%$ \\
\hline
\end{tabular}

(a) Distribution of respondents by stated future use

\begin{tabular}{|c|c|c|c|c|c|c|c|c|c|c|c|c|}
\hline & \multicolumn{4}{|c|}{ Most informative } & \multicolumn{4}{|c|}{ Easiest to understand } & \multicolumn{4}{|c|}{ Preferred } \\
\hline & \multicolumn{2}{|c|}{ England } & \multicolumn{2}{|c|}{ US } & \multicolumn{2}{|c|}{ England } & \multicolumn{2}{|c|}{ US } & \multicolumn{2}{|c|}{ England } & \multicolumn{2}{|c|}{ US } \\
\hline & $\mathrm{n}$ & $\%$ & $\mathrm{n}$ & $\%$ & $\mathrm{n}$ & $\%$ & $\mathrm{n}$ & $\%$ & $\mathrm{n}$ & $\%$ & $\mathrm{n}$ & $\%$ \\
\hline IS cohort & & & & & & & & & & & & \\
\hline CEO-MW & 65 & 68.42 & 122 & 62.89 & 64 & 67.37 & 116 & 59.79 & 65 & 68.42 & 123 & 63.40 \\
\hline IS & 13 & 13.68 & 29 & 14.95 & 17 & 17.89 & 40 & 20.62 & 13 & 13.68 & 44 & 22.68 \\
\hline Same / Indifferent & 17 & 17.89 & 43 & 22.16 & 14 & 14.74 & 38 & 19.59 & 17 & 17.89 & 27 & 13.92 \\
\hline GI cohort & & & & & & & & & & & & \\
\hline CEO-MW & 63 & 61.76 & 83 & 45.36 & 74 & 72.55 & 100 & 54.64 & 68 & 66.67 & 90 & 49.18 \\
\hline GI & 19 & 18.63 & 43 & 23.50 & 8 & 7.84 & 40 & 21.86 & 21 & 20.59 & 49 & 26.78 \\
\hline Same / Indifferent & 20 & 19.61 & 57 & 31.15 & 20 & 19.61 & 43 & 23.50 & 13 & 12.75 & 44 & 24.04 \\
\hline 2D cohort & & & & & & & & & & & & \\
\hline CEO-MW & 17 & 23.29 & 49 & 30.06 & 36 & 49.32 & 81 & 49.69 & 16 & 21.92 & 57 & 34.97 \\
\hline $2 \mathrm{D}$ & 43 & 58.90 & 78 & 47.85 & 21 & 28.77 & 34 & 20.86 & 43 & 59.80 & 76 & 46.63 \\
\hline Same / Indifferent & 13 & 17.81 & 36 & 22.03 & 16 & 21.92 & 48 & 29.45 & 14 & 19.18 & 30 & 18.40 \\
\hline
\end{tabular}

(b) Distribution of opinions about the inequality reporting formats.

\begin{tabular}{|c|c|c|c|c|c|c|c|}
\hline & & & $\begin{array}{c}\text { Strongly } \\
\text { agree }\end{array}$ & $\begin{array}{c}\text { Somewhat } \\
\text { agree }\end{array}$ & $\begin{array}{c}\text { Neither agree } \\
\text { nor disagree }\end{array}$ & $\begin{array}{c}\text { Somewhat } \\
\text { disagree }\end{array}$ & $\begin{array}{l}\text { Strongly } \\
\text { disagree }\end{array}$ \\
\hline \multirow{6}{*}{ 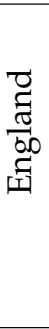 } & Differences & $\mathrm{n}$ & 120 & 109 & 23 & 14 & 4 \\
\hline & & $\%$ & $44.44 \%$ & $40.37 \%$ & $8.52 \%$ & $5.19 \%$ & $1.48 \%$ \\
\hline & Deserving & $\mathrm{n}$ & 4 & 57 & 94 & 89 & 26 \\
\hline & & $\%$ & $1.48 \%$ & $21.11 \%$ & $34.81 \%$ & $32.96 \%$ & $9.63 \%$ \\
\hline & Government & $\mathrm{n}$ & 72 & 115 & 40 & 31 & 12 \\
\hline & & $\%$ & $26.67 \%$ & $42.59 \%$ & $14.81 \%$ & $11.48 \%$ & $4.44 \%$ \\
\hline \multirow{6}{*}{ ص } & Differences & $\mathrm{n}$ & 275 & 155 & 75 & 20 & 15 \\
\hline & & $\%$ & $50.93 \%$ & $28.70 \%$ & $13.89 \%$ & $3.70 \%$ & $2.78 \%$ \\
\hline & Deserving & $\mathrm{n}$ & 64 & 165 & 158 & 95 & 58 \\
\hline & & $\%$ & $11.85 \%$ & $30.56 \%$ & $29.26 \%$ & $17.59 \%$ & $10.74 \%$ \\
\hline & Government & $\mathrm{n}$ & 110 & 149 & 107 & 78 & 96 \\
\hline & & $\%$ & $20.37 \%$ & $27.59 \%$ & $19.81 \%$ & $14.44 \%$ & $17.78 \%$ \\
\hline \multicolumn{8}{|c|}{$\begin{array}{l}\text { Note: The mode is highlighted in bold. The variables correspond to the answers to the questions listed in } \\
\text { Table C.10 (Section C.2, on a 5-point Likert scale from Strongly agree to Strongly disagree. They questions are: } \\
\text { To what extent do you agree or disagree with the following statements? (Differences) Differences in income } \\
\text { in the United Kingdom / United States are too large; (Deserving) Most of the time, people with high incomes } \\
\text { deserve their high incomes; (Government) It is the responsibility of the government to reduce the differences } \\
\text { in income between people with high incomes and those with low incomes. }\end{array}$} \\
\hline
\end{tabular}

(c) Distribution of attitudes to Income Inequality

Table B.9: Distributions of stated future us 26 opinions about the inequality formats and attitudes to inequality. 


\section{Supplementary Information}

\section{C.1 Supplementary Results}

\section{C.1.1 Willingness to pay: descriptive statistics and basic tests}

Summary statistics for WTP across all reporting formats and inequality levels is given in Table C.1. In this table, we state the values for the US study in dollars and pounds for comparison, with the dollar values converted into pounds using the exchange rate on the first day of the US study (24 November, 2020). Table C.2 displays regressions of the WTP for the largest inequality reduction against stated future use, for each country and under each of the reporting formats.

Table C.1: Summary statistics: WTP for reduced inequality across reporting formats and levels of reduced inequality

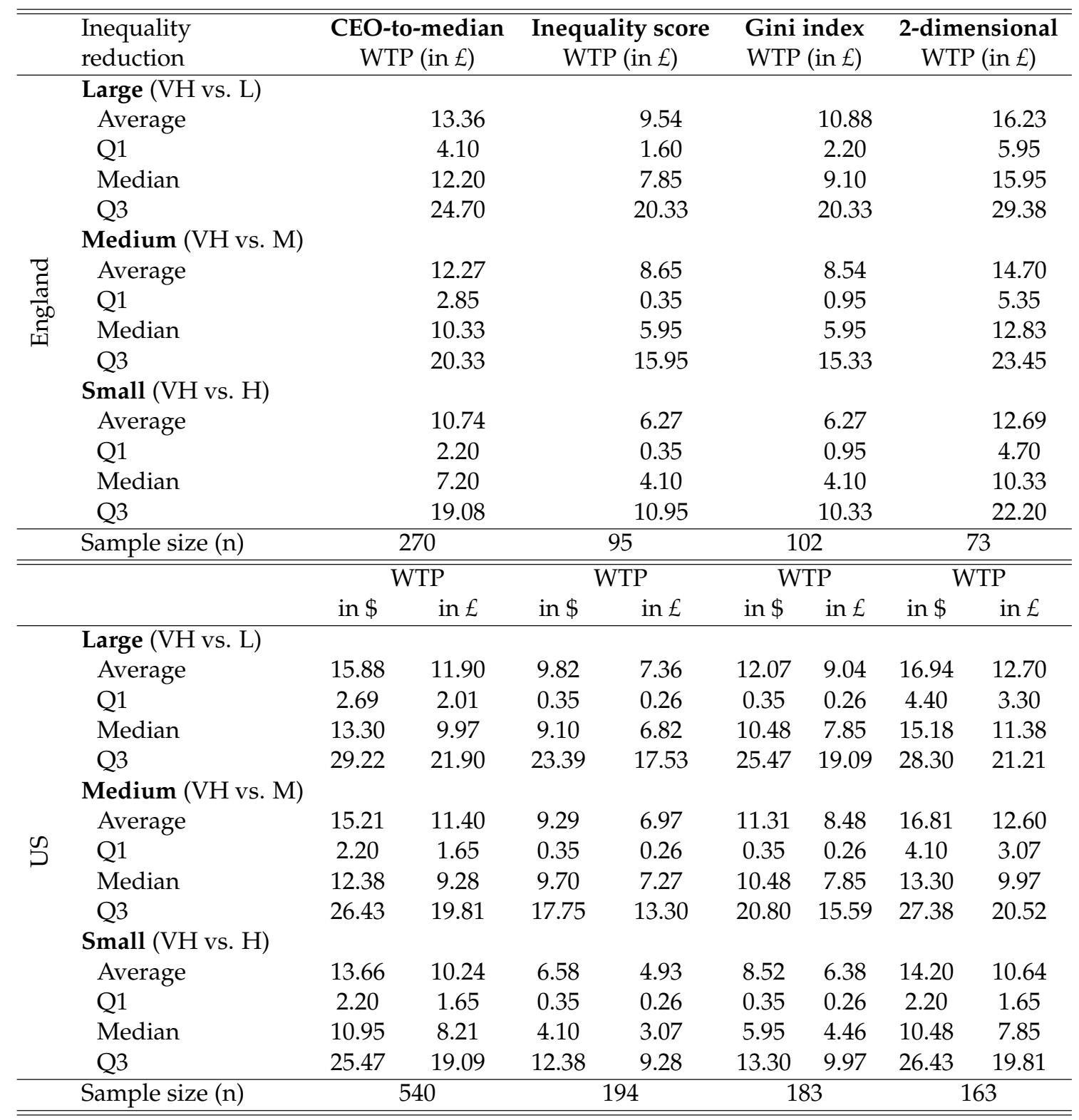


Table C.2: Regression of WTP for largest reduction in inequality against stated future use

\begin{tabular}{|c|c|c|c|c|c|}
\hline & & $\begin{array}{c}\text { WTP } \\
\text { CEO-to-median } \\
\beta / \mathrm{SE}\end{array}$ & $\begin{array}{c}\text { WTP } \\
\text { Ineq. score } \\
\beta / \text { SE }\end{array}$ & $\begin{array}{c}\text { WTP } \\
\text { Gini index } \\
\beta / \mathrm{SE}\end{array}$ & $\begin{array}{c}\text { WTP } \\
\text { 2-dimensional } \\
\beta / \mathrm{SE}\end{array}$ \\
\hline \multirow{11}{*}{ 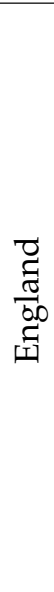 } & \multicolumn{5}{|c|}{ Stated future use (baseline: Definitely yes) } \\
\hline & Probably yes & $\begin{array}{c}-7.011^{* * *} \\
(1.399)\end{array}$ & $\begin{array}{c}1.582 \\
(3.128)\end{array}$ & $\begin{array}{c}-8.983^{* * *} \\
(2.358)\end{array}$ & $\begin{array}{l}-4.053 \\
(2.944)\end{array}$ \\
\hline & Might or might not & $\begin{array}{c}-13.34^{* * *} \\
(1.692)\end{array}$ & $\begin{array}{l}-6.176 \\
(3.725)\end{array}$ & $\begin{array}{c}-13.90^{* * *} \\
(2.886)\end{array}$ & $\begin{array}{c}-12.55^{* * *} \\
(3.474)\end{array}$ \\
\hline & Probably not & $\begin{array}{c}-16.02^{* * *} \\
(2.007)\end{array}$ & $\begin{array}{c}-5.214 \\
(4.201)\end{array}$ & $\begin{array}{c}-12.09^{* *} \\
(3.674)\end{array}$ & $\begin{array}{c}-14.66^{* * *} \\
(4.021)\end{array}$ \\
\hline & \multirow[t]{2}{*}{ Definitely not } & $-18.40^{* * *}$ & $-14.89^{+}$ & $-22.54^{* * *}$ & $-18.62^{*}$ \\
\hline & & $(3.468)$ & $(7.494)$ & (5.755) & $(7.505)$ \\
\hline & \multirow[t]{2}{*}{ Constant } & $20.85^{* * *}$ & $11.25^{* * *}$ & $19.34^{* * *}$ & $22.40^{* * *}$ \\
\hline & & $(1.058)$ & $(2.194)$ & $(1.918)$ & $(2.166)$ \\
\hline & Observations & 270 & 95 & 102 & 73 \\
\hline & R-squared & 0.286 & 0.094 & 0.260 & 0.261 \\
\hline & Prob $>$ F & 0.000 & 0.062 & 0.000 & 0.000 \\
\hline \multirow{13}{*}{$\stackrel{\omega}{\rho}$} & \multicolumn{5}{|c|}{ Stated future use (baseline: Definitely yes) } \\
\hline & Probably yes & $\begin{array}{c}-4.605^{* * *} \\
(1.660)\end{array}$ & $\begin{array}{c}-9.862^{* * *} \\
(2.977)\end{array}$ & $\begin{array}{c}1.985 \\
(2.840)\end{array}$ & $\begin{array}{l}-2.061 \\
(2.978)\end{array}$ \\
\hline & \multirow[t]{2}{*}{ Might or might not } & $-11.20^{* * *}$ & $-13.81^{* * *}$ & $-7.480^{* *}$ & -5.252 \\
\hline & & $(1.806)$ & $(3.331)$ & $(2.972)$ & $(3.266)$ \\
\hline & \multirow[t]{2}{*}{ Probably not } & $-18.08^{* * *}$ & $-17.35^{* * *}$ & $-12.51^{* * *}$ & $-15.07^{* * *}$ \\
\hline & & $(2.167)$ & $(4.252)$ & (3.410) & $(3.901)$ \\
\hline & \multirow[t]{2}{*}{ Definitely not } & $-18.18^{* * *}$ & $-13.61^{* *}$ & $-10.28^{*}$ & $-18.09^{* *}$ \\
\hline & & (3.332) & $(5.363)$ & (5.816) & (6.991) \\
\hline & \multirow[t]{2}{*}{ Constant } & $23.05^{* * *}$ & $18.90^{* * *}$ & $15.63^{* * *}$ & $21.30^{* * *}$ \\
\hline & & $(1.222)$ & $(2.241)$ & $(2.056)$ & $(2.168)$ \\
\hline & Observations & 540 & 194 & 183 & 163 \\
\hline & R-squared & 0.156 & 0.122 & 0.130 & 0.115 \\
\hline & Prob $>F$ & 0.000 & 0.000 & 0.000 & 0.001 \\
\hline
\end{tabular}

\section{C.1.2 WTP and size of inequality reduction}

Table C.3 presents one-way ANOVAs with repeated measures of WTP against levels of inequality reduction, for each country and inequality format. Table C.4 reports $t$-tests and Wilcoxon tests where the null hypothesis is that the mean WTP for the reduction to the two intermediate inequality levels under the $2 \mathrm{D}$ format are the same. It also reports counts for the ordering between the WTP for these two inequality levels.

\section{C.1.3 WTP and Political Leanings}

Table C.5 reports the same analyses and tests as Table B.4 for $W T P_{\min }$ under the other formats, across inequality reductions and political leanings. 
Table C.3: Repeated measures ANOVA of WTP (dependent variable) against the level of inequality reduction (factor).

\begin{tabular}{|c|c|c|c|c|c|}
\hline & & $(1)$ & $(2)$ & (3) & $(4)$ \\
\hline & & CEO-to-median & Inequality score & Gini index & 2-dimensional \\
\hline \multirow{5}{*}{ 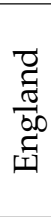 } & $d f_{\text {inequ redn }}$ & 2 & 2 & 2 & 2 \\
\hline & $d f_{\text {residual }}$ & 538 & 188 & 202 & 144 \\
\hline & $\mathrm{F}$ & 48.71 & 9.13 & 25.74 & 229.4 \\
\hline & $\mathrm{p}$ & 0.000 & 0.001 & 0.000 & 0.001 \\
\hline & $\eta_{p}^{2}$ & 0.15 & 0.09 & 0.20 & 0.13 \\
\hline \multirow{5}{*}{$\stackrel{\omega}{\rho}$} & $\bar{c} d f_{\text {inequ redn }}$ & 2 & 2 & 2 & 2 \\
\hline & $d f_{\text {residual }}$ & 1078 & 386 & 364 & 324 \\
\hline & $\mathrm{F}$ & 20.38 & 6.74 & 11.39 & 5.53 \\
\hline & $\mathrm{p}$ & 0.000 & 0.002 & 0.000 & 0.006 \\
\hline & $\eta_{p}^{2}$ & 0.04 & 0.03 & 0.06 & 0.03 \\
\hline
\end{tabular}

Table C.4: 2D format: comparison of WTP across intermediate levels 300:1 ; 3:1 and 30:1 ; 1:3: two-sample paired $t$-tests, Wilcoxon signed-rank tests and counts

\begin{tabular}{lcccc}
\hline \hline$t$-test & $d f$ & $t$ & $p$ & $d_{z}$ \\
\hline England & 72 & 2.24 & 0.028 & 0.26 \\
US & 162 & 2.44 & 0.015 & 0.19 \\
\hline \hline Wilcoxon & $z$ & $p$ & $r$ & \\
\hline England & 1.92 & 0.054 & 0.22 & \\
US & 2.45 & 0.014 & 0.19 & \\
\hline \hline Counts & $\# 300: 1 ; 3: 1>30: 1 ; 1: 3$ & $\# 300: 1 ; 3: 1=30: 1 ; 1: 3$ & $\# 300: 1 ; 3: 1<30: 1 ; 1: 3$ & Total \\
\hline England & 23 & 36 & 14 & 73 \\
& $(32 \%)$ & $(49 \%)$ & $(19 \%)$ & $(100 \%)$ \\
US & 54 & 75 & 34 & 163 \\
& $(33 \%)$ & $(46 \%)$ & $(21 \%)$ & $(100 \%)$ \\
\hline \hline
\end{tabular}

\section{C.2 Further details of experimental design}

Table C.6 provide summaries of the inequality reductions used in the experiment, and Table C.8 provides a summary of the relationship between the $2 \mathrm{D}$ inequality levels used and the CEO-MW format. Table C.9 displays the details of the goods used for remunerating subjects.

Inequality levels We set the CEO-MW inequality levels used in the experiment relying on the ISSP 2009 data on 'ideal' CEO and median worker pay [12, 13], the distribution of CEO-to-median pay ratios among the 265 companies in the Consumer Discretionary category (relevant for the textile industry) and among the 2054 Russell 3000 companies in the AFL-CIO data set [10], as well as the CEO-to-average pay ratios of 99 FTSE 100 companies in the CIPD data set [39], displayed in Table C.7 ${ }^{13}$ Our very high inequality 'benchmark' level in the CEO-MW format, 750:1, corresponds to the 86th percentile of companies in the Consumer Discretionary industry and the 97th percentile of all companies in the AFL-CIO

\footnotetext{
${ }^{13}$ Although CEO-to-average and CEO-to-median pay ratios are not directly comparable (with the mean employee pay often above the median employee pay), we also consider the CIPD UK data set since one of the studies is run in the UK where CEOs of large corporations tend to be paid less than their US counterparts.
} 
Table C.5: Sample means and one-sample t-tests of $W T P_{\min }$ by political ideology for IS, GI and $2 \mathrm{D}$ formats. $\mathrm{WTP}_{\min }$ reported in $£$ for England and in $\$$ for the US.

\begin{tabular}{|c|c|c|c|c|c|}
\hline & \multicolumn{3}{|c|}{ Inequality Score (average $W T P_{\min }$ ) } & \multirow[t]{2}{*}{ Observations } \\
\hline & & E vs. D & E vs. B & E vs. A & \\
\hline \multirow{5}{*}{ 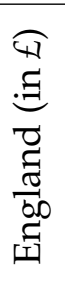 } & Left & $4.47^{* *}$ & $7.99^{* *}$ & $9.77^{* * *}$ & 31 \\
\hline & & $(1.54)$ & $(2.23)$ & $(2.21)$ & \\
\hline & Centre & $7.37^{* * *}$ & $8.34^{* * *}$ & $9.21^{* * *}$ & 45 \\
\hline & & $(1.73)$ & $(1.96)$ & $(2.03)$ & \\
\hline & Right & $\begin{array}{l}6.62^{* *} \\
(2.04)\end{array}$ & $\begin{array}{c}10.46^{* * *} \\
(229)\end{array}$ & $\begin{array}{l}9.92^{* *} \\
(2.73)\end{array}$ & 19 \\
\hline \multirow{6}{*}{ 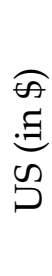 } & Liberal & $7.66^{* * *}$ & $13.12^{* * *}$ & $14.92^{* * *}$ & 49 \\
\hline & & $(2.06)$ & $(2.49)$ & $(2.56)$ & \\
\hline & Moderate & $7.59^{* * *}$ & $9.00^{* * *}$ & $9.92^{* * *}$ & 82 \\
\hline & & $(1.66)$ & $(1.82)$ & $(1.86)$ & \\
\hline & Conservative & $3.32^{*}$ & $5.53 * *$ & $4.54^{*}$ & 63 \\
\hline & & $(1.62)$ & $(1.73)$ & (1.93) & \\
\hline \multirow{8}{*}{ 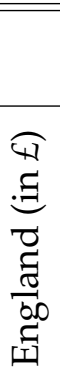 } & & \multicolumn{3}{|c|}{ Gini index (average $\left.W T P_{\min }\right)$} & Observations \\
\hline & & 0.55 vs. 0.45 & 0.55 vs. 0.25 & 0.55 vs. 0.15 & \\
\hline & Left & $8.85^{* * *}$ & $10.07^{* * *}$ & $13.31^{* * *}$ & 33 \\
\hline & & $(1.45)$ & $(1.91)$ & $(1.87)$ & \\
\hline & Centre & $6.06^{* * *}$ & $8.62^{* * *}$ & $10.69^{* * *}$ & 48 \\
\hline & & $(1.34)$ & $(1.53)$ & $(1.66)$ & \\
\hline & Right & $2.72^{*}$ & $5.93^{* * *}$ & $7.50^{* * *}$ & 21 \\
\hline & & $(1.08)$ & $(1.41)$ & $(1.72)$ & \\
\hline \multirow{8}{*}{$\begin{array}{l}\mathscr{\mathscr { E }} \\
\stackrel{\Xi}{\Xi} \\
\stackrel{\mathscr{D}}{\sigma}\end{array}$} & Liberal & $9.75^{* * *}$ & $14.91^{* * *}$ & $16.08^{* * *}$ & 45 \\
\hline & & $(1.92)$ & $(1.99)$ & $(1.99)$ & \\
\hline & Moderate & $7.92^{* * *}$ & $9.78^{* * *}$ & $9.66^{* * *}$ & 88 \\
\hline & & $(1.29)$ & $(1.64)$ & $(1.64)$ & \\
\hline & Conservative & $7.07^{* * *}$ & $9.38^{* * *}$ & $11.29^{* * *}$ & 50 \\
\hline & & $(1.85)$ & $(1.96)$ & $(2.29)$ & \\
\hline & & \multicolumn{3}{|c|}{ 2-dimensional (average $W T P_{\min }$ ) } & Observations \\
\hline & & $\begin{array}{c}300: 1 ; 1: 3 \text { vs. } \\
30: 1 ; 1: 3\end{array}$ & $\begin{array}{c}300: 1 ; 1: 3 \text { vs. } \\
300: 1 ; 3: 1\end{array}$ & $\begin{array}{c}300: 1 ; 1: 3 \text { vs. } \\
30: 1 ; 3: 1\end{array}$ & \\
\hline \multirow{6}{*}{ 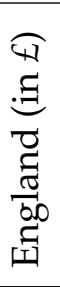 } & Left & $15.23^{* * *}$ & $17.79^{* * *}$ & $20.23^{* * *}$ & 23 \\
\hline & & $(2.23)$ & $(2.15)$ & $(2.24)$ & \\
\hline & Centre & $12.06^{* * *}$ & $14.22^{* * *}$ & $15.51^{* * *}$ & 42 \\
\hline & & $(1.83)$ & $(1.71)$ & (1.79) & \\
\hline & Right & $8.50^{*}$ & $8.34^{*}$ & $8.74^{*}$ & 8 \\
\hline & & (3.24) & (3.27) & (3.19) & \\
\hline \multirow{6}{*}{$\begin{array}{l}\mathscr{\oplus} \\
\stackrel{\Xi}{\Xi} \\
\mathscr{D}\end{array}$} & Liberal & $19.08^{* * *}$ & $20.61^{* * *}$ & $22.62^{* * *}$ & 41 \\
\hline & & $(2.16)$ & $(2.19)$ & (2.39) & \\
\hline & Moderate & $14.53^{* * *}$ & $17.83^{* * *}$ & $17.82^{* * *}$ & 62 \\
\hline & & $(1.80)$ & $(1.78)$ & $(1.78)$ & \\
\hline & Conservative & $9.54^{* * *}$ & $12.18^{* * *}$ & $11.15^{* * *}$ & 60 \\
\hline & & $(1.95)$ & $(2.06)$ & $(2.05)$ & \\
\hline
\end{tabular}


sample. The low level, 5:1, corresponds to the 'ideal' CEO-MW in the ISSP 2009 data: the median ideal CEO-to-median worker pay ratio is 5.3:1 in the UK sample ( $n=808$, [13]; it is 6.7:1 in the US sample; $n=1,378)$. It corresponds to the 9th percentile of all companies in the AFL-CIO sample. Our intermediate inequality levels were selected to span the range of percentiles, whilst being multiples of 10 and dividers of 750. The medium level, 50:1, is located below the first quartile for the Consumer Discretionary group and between the first quartile and the median for both the entire US and UK sample, whereas the high level, 250:1, is located between the median and the third quartile for the Consumer Discretionary group and between the third quartile and the 90th percentile for the entire US and UK sample.

Every effort was made to calibrate the inequality levels under the other formats with those set for the CEO-MW. As noted in the Introduction, Gini indices are frequently used to measure country-level income inequality, though significantly less so for firm-level inequality. The inequality levels under the GI used here (i.e. 0.15, 0.25, 0.45 and 0.55) were thus based on the distribution of Gini indices at the country level [40] - which range from 0.24 for Slovenia (in 2017) to 0.63 for South African (in 2014)—mirroring the percentile rank of our CEO-MW ratio levels, as well as the few data points we could find on the GI at the company level ${ }^{14}$ For the Inequality Score, we assigned " $\mathrm{A}$ " to reflect the 'ideal' CEOMW of 5:1, and "E" to mirror the very high level of 750:1. On the basis of the location of the CEO-MW levels with respect to the median (Table C.7), we assigned a value of " $\mathrm{D}$ " to roughly correspond to the 250:1 level, and a value of " $\mathrm{B}$ " for the 50:1 level. The calibration in the case of the $2 \mathrm{D}$ CEO-to-minimum wage / Median-to-minimum wage ratio is facilitated by the fact that the CEO-MW value can be derived from the $2 \mathrm{D}$ one; these translations are given in Table C.8. Clearly, the very high and low inequality levels under the $2 \mathrm{D}$ format correspond to CEO-to-median worker pay ratios that are comparable to the corresponding levels under the CEO-MW formats. The choice of 1:3 median-to-minimum wage ratio for the very high level is based on data from the Consumer Discretionary dataset [10], according to which 16 companies (resp. 5 companies) out of 265 have a median-to-UK minimum wage (resp. median-to-US minimum wage) ratio smaller than or equal to $1: 3,15$ The intermediate 2D levels were chosen such that, for each of them, only one of up-side vs. down-side inequality differs with respect to high and low 2D levels, and so that their corresponding CEO-MW levels are comparable.

Elicitation technique For the benchmark price and inequality level ( price $_{B}$, inequ $u_{B}$ ) and each inequality level $i n e q u_{n}$ (see Table 1), we elicted the indifference point: the price price $_{n}$ such that the subject was indifferent between a towel set with $\left(\right.$ price $_{B}$, inequ $\left._{B}\right)$ and one with $\left(\right.$ price $_{n}$, inequ $\left._{n}\right)$. This was done through a chained sequence of binary-choice questions between a towel set with fixed inequality and price $\left(\right.$ price $_{B}$, inequ $\left._{B}\right)$ and towel sets with

\footnotetext{
${ }^{14}$ Specifically, the only study we could find reporting company-level Gini index [41] reports the 'Corporate Gini index' for a multi-national retail company as ranging from 0.16 to 0.25 whereas the CEO-MW ranged from 55:1 to 71:1. Data concerning a software company which implements the policy of making the pay of all its employees publicly available indicate a GI of 0.16 and CEO-MW of 2:1.

${ }^{15}$ The 2019 UK minimum hourly wage is $£ 8.21$; the US minimum wage is $\$ 7.25$.
} 
$\left(\right.$ price $_{i}$, inequ $\left._{n}\right)$, where the inequality remains fixed and the price varies across questions

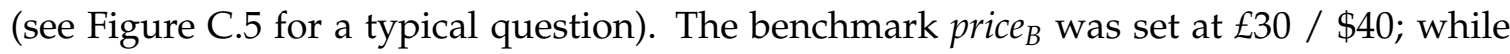
price $_{i}$, initially set at $£ 30 / \$ 40$, varied in increments, with a lower bound of $£ 10$ / $\$ 15$ and an upper bound of $£ 60 / \$ 80$. The first two binary choices in each sequence, for price $_{i}=£ 30, £ 40$ (\$40, \$50 in the US study), were the same for all participants. Subsequent binary choices followed the logic of the bisection process, with the varying parameter $\left(\right.$ price $\left._{i}\right)$ determined by previous choices. It was designed such that price $_{i+1}>$ price $_{i}$ (resp. price $_{i+1}<$ price $_{i}$ ) if the $\left(\right.$ price $_{i}$, inequ $\left._{n}\right)$ good was chosen (resp. not chosen) in the previous question. More specifically, let price be the largest price ${ }_{i}$ such that $\left(\right.$ price $_{i}$, inequ $\left._{n}\right)$ is chosen over $\left(\right.$ price $_{B}$, ineq $u_{B}$ ) in some choice (and set it at $-\infty$ if there is no such choice), and $\overline{\text { price }}$ be the smallest

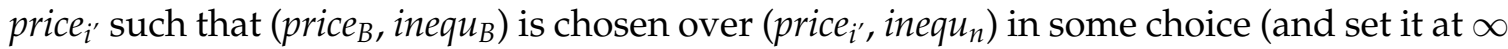
if there is no such choice). It follows that the subject's indifference point lies in the interval $[$ price $\overline{\text { price }}]$. At each stage in the sequence, if the interval thus defined on the basis of previous choices did not stretch to $\infty$ or $-\infty$, the next question involved the mid-point price $\frac{1}{2}(\overline{\text { price }}+$ price $)$ (so, at the subsequent stage, the size of the interval was halved). If there were no choices in which the subject has chosen $\left(\right.$ price $_{B}$, inequ $\left._{B}\right)($ so $\overline{\text { price }}=\infty)$, the subsequent choice involved the price $£ 10$ higher ( $\$ 15$ in the US study) than the largest price yet faced by the subject; and similarly for price $=-\infty$. The procedure stopped when the width of the interval $[$ price, $\overline{\text { price }}]$ was at most $£ 1.00 / \$ 1.00$ or when the limit of the range for price $_{i}$ was reached; it was designed such that there were at most 7 binary choices.

At the end, the indifference point price $_{n}$ was taken to be the midpoint of the interval

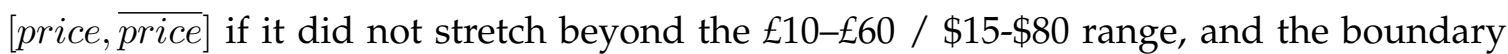
point reached if it did. The WTP for the reduction in inequality from $i n e q u_{B}$ to $i n e q u_{n}$ is price $_{n}-$ price $_{B}$. Note that our elicitation only situates the indifference price in the interval $[$ price, $\overline{\text { price }}]$, so the most conservative estimate for this price (in the context of this study, which is focused on the possibility of positive WTP) is price. Hence we define the lowest possible WTP coherent with the subject's choices, $W T P_{\min }=$ price $_{- \text {price }_{B}}{ }^{16} W T P_{\min }$ is more relevant than WTP for testing positivity of WTP, for it guarantees that results are not driven by the arbitrary choice of the midpoint of $[\underline{\text { price }}, \overline{\text { price }}]$ as our indifference point.

Screenshots and survey questions Figures C.1 C.4 provide screenshots of the Instruction screens and the two types of comprehension question, whereas Figure C.5 shows a typical binary choice question. Table C.10 lists the end-of-experiment survey questions.

\footnotetext{
${ }^{16}$ In the case where price $=-\infty, W T P_{\min }$ is set at -20 ( -25 in the US study), corresponding to the lower bound of the price range, $£ 10$ (\$15 in the US study).
} 


\begin{tabular}{lllll}
\hline \hline & CEO-to-median & Gini Index & CEO-MW \& Median-MW & A-E scale \\
\hline VH vs. L & $750: 1$ vs. $5: 1$ & 0.55 vs. 0.15 & $300: 1 ; 1: 3$ vs. $30: 1 ; 3: 1$ & E vs. A \\
VH vs. M & $750: 1$ vs. $50: 1$ & 0.55 vs. 0.25 & $300: 1 ; 1: 3$ vs. $300: 1 ; 3: 1$ & E vs. B \\
VH vs. H & $750: 1$ vs. $250: 1$ & 0.55 vs. 0.45 & $300: 1 ; 1: 3$ vs. $30: 1 ; 1: 3$ & E vs. D \\
\hline \multicolumn{4}{c}{ Note: VH stands for very high, $\mathrm{H}$ for high, M for medium and L for low. }
\end{tabular}

Table C.6: Summary of inequality level reductions used in the experiment Since the 2D format the intermediate levels are not unequivocally ordered by inequality (Table 1), the $\mathrm{H}, \mathrm{M}$ coding introduced here is merely for expository purposes.

\begin{tabular}{lcc|c}
\hline \hline & \multicolumn{2}{c|}{$\begin{array}{c}\text { CEO-to-median pay ratio } \\
\text { (AFL-CIO, US companies) }\end{array}$} & $\begin{array}{c}\text { CEO-to-average pay ratio } \\
\text { (CIPD, UK companies) }\end{array}$ \\
\hline & Consumer Discretionary & All industries & FTSE 100 \\
\hline Min & $1: 1$ & $1: 1$ & $12: 1$ \\
10th Percentile & $45: 1$ & $19: 1$ & $28: 1$ \\
25th Percentile & $80: 1$ & $39: 1$ & $40: 1$ \\
Median & $194: 1$ & $80: 1$ & $72: 1$ \\
75th Percentile & $481: 1$ & $164: 1$ & $138: 1$ \\
90th Percentile & $917: 1$ & $324: 1$ & $301: 1$ \\
Max & $40668: 1$ & $40668: 1$ & $956: 1$ \\
\hline Observations & 265 & 2054 & 99 \\
\hline Sources: [10, 39]. & &
\end{tabular}

Table C.7: Distribution of pay ratios for publicly listed companies (FYE2018)

\begin{tabular}{lccc}
\hline \hline Inequality & Up-side inequality / & CEO-to-Min Wage; & Corresponding \\
level & Down-side inequality & Median-to-Min Wage & CEO-MW \\
\hline Very high & (High, High) & $300: 1 ; 1: 3$ & $900: 1$ \\
& (Low, High) & $30: 1 ; 1: 3$ & $90: 1$ \\
& (High, Low) & $300: 1 ; 3: 1$ & $100: 1$ \\
Low & (Low, Low) & $30: 1 ; 3: 1$ & $10: 1$ \\
\hline
\end{tabular}

Table C.8: Summary of the 2-dimensional inequality levels

\begin{tabular}{cccc|ccc}
\hline \multirow{2}{*}{ Product } & \multicolumn{2}{c|}{ Used for remuneration } & \multicolumn{3}{c}{ Choice question } \\
\cline { 2 - 6 } & Inequality & \multicolumn{2}{c}{ Price } & Inequality & \multicolumn{2}{c}{ Price } \\
& & England & US & & England & US \\
\hline 1 & $785: 1$ & $£ 29.43$ & $\$ 39.99$ & $750: 1$ & $£ 30$ & $\$ 40$ \\
2 & $2: 1(\mathrm{CEO})$ & $£ 37.99$ & $\$ 50.99$ & $5: 1$ & $£ 40$ & $\$ 50$ \\
\hline
\end{tabular}

Table C.9: Inequality and price for 6-piece white cotton towel set used for remuneration of subjects. Inequality is given in the CEO-MW ratio, though for the second product, we also give the ratio of the $\mathrm{CFO}$-median worker pay ratio, the $\mathrm{CFO}$ being the highest paid employee. 
Please read these instructions carefully. After them, you will be asked several questions to check that you have understood them clearly.

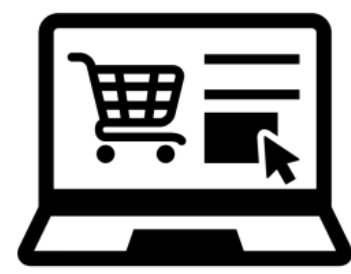

Imagine that you are in the following situation:

You are shopping online for new towels and have a budget of $£ 50$ for this purchase. After having browsed for different options, you have found suitable offers for a 6-piece $100 \%$ cotton white towel set from different popular retailing brands. The towel sets are comparable in every way except for the price and the inequality in income across employees of the company producing and selling the product.

This section of the survey will comprise of a series of questions. In each question, you will have the choice between two such comparable towel sets, with the price and the inequality level of each set as indicated. You will not be told the brand of each towel set.

Figure C.1: First page of the Instructions

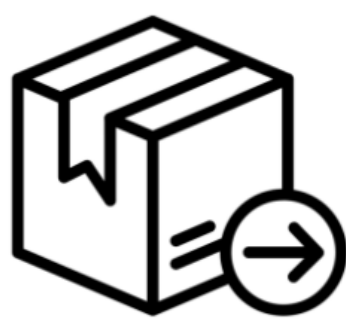

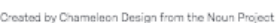

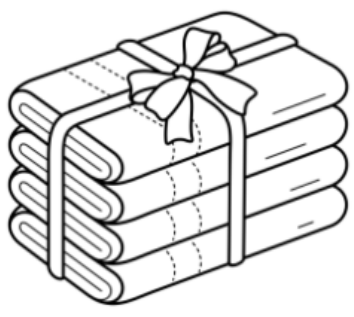

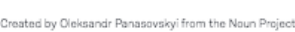

You have a chance of being randomly selected among all participants to receive a $£ 50$ budget and have one of your purchasing decisions played for real. So it is important that you answer all the questions honestly: i.e. choose the towel set, with price and inequality characteristics, which you really prefer buying.

More specifically, once everyone has completed the survey, the program will automatically select several participants and one purchase question for each of these participants. Each participant has an equal, better than 1 in a 100 chance of being selected. Each selected participant will be allocated the $£ 50$ budget, and the "purchase" in the selected question will be made according to the choice they stated during the survey. They will then be sent the purchased product and any change from $£ 50$.

Figure C.2: Second page of the Instructions 
The price and the income inequality level

The quality and the income inequality level

The price and the quality

Each participant has an equal chance of receiving a towel set and change from £50, and which set

and change he or she gets depends on the choices he or she makes.

Every participant will receive the same towel set and change from £50, irrespective of their choices.

No survey participant will receive anything on the basis of their choices.

\title{
Figure C.3: General comprehension check (immediately after the instructions)
}

\begin{abstract}
In the following 3 series of questions, the inequality in income across employees of the company producing and selling each towel set will be reported in the form of the CEO-tomedian pay ratio.

The CEO-to-median pay ratio of a company is how many times more the company's Chief Executive Officer (CEO) earns compared to its average worker. So the CEO-to-median pay ratio is 500 when the CEO earns 500 times more than the average worker.

The CEO is the top management position in the company. Here, the pay of the average worker is calculated as the median pay of the company's employees (which means that $50 \%$ of employees at the company earn more than the average worker pay and $50 \%$ of employees earn less).
\end{abstract}

To verify that these indications were clear, consider the following companies, with the income inequality across employees indicated for each. Please rank them, using drag and drop, from highest inequality (at the top) to lowest inequality (at the bottom).

(1) The CEO earns 5 times more than the average worker.

(2) The CEO earns 750 times more than the average worker.

3 The CEO earns 150 times more than the average worker.

Figure C.4: Inequality reporting format comprehension check (this example for CEO-MW format) 
Figure C.5: Example of a binary choice for the CEO-MW format

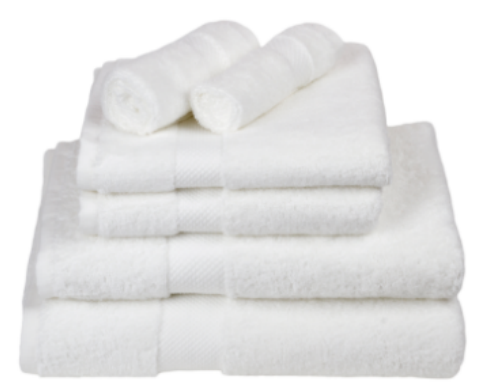

$£ 30.00$

Inequality: The CEO earns 750 times more than the average worker.

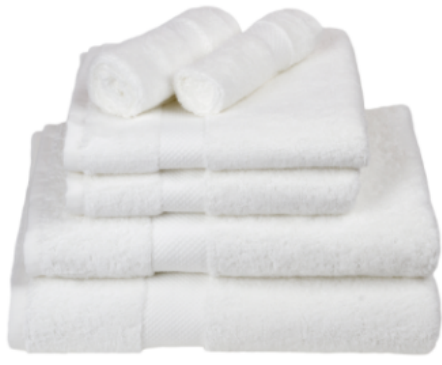

$£ 35.00$

Inequality: The CEO earns $\mathbf{5}$ times more than the average worker.

Which of these two towel sets do you wish to buy?

The left one Price: $£ 30.00$ Inequality: 750 times more
The right one

Price: $£ 35.00$

Inequality: 5 times more 
Table C.10: Survey questions

\begin{tabular}{|c|c|c|}
\hline Topic / name & Question & Response format \\
\hline \multicolumn{3}{|l|}{ Inequality reporting } \\
\hline Informativity & $\begin{array}{l}\text { Of the two reporting formats, which do you find } \\
\text { the most informative? }\end{array}$ & $\begin{array}{l}\text { Format } 1 / 2 \text { / } \\
\text { Same }\end{array}$ \\
\hline Understandability & $\begin{array}{l}\text { Of the two reporting formats, which is the easiest } \\
\text { to understand? }\end{array}$ & $\begin{array}{l}\text { Format } 1 \text { / } 2 \text { / } \\
\text { Same }\end{array}$ \\
\hline Preference & $\begin{array}{l}\text { If inequality was to be reported in any of the two } \\
\text { reporting formats, which would you prefer? }\end{array}$ & $\begin{array}{l}\text { Format } 1 \text { / } 2 \text { / In- } \\
\text { different }\end{array}$ \\
\hline Future use & $\begin{array}{l}\text { If information about the level of inequality of com- } \\
\text { panies involved in the production of goods were } \\
\text { available, would you use it when shopping? }\end{array}$ & 5-point Likert \\
\hline \multicolumn{3}{|c|}{ Attitudes towards inequality } \\
\hline & \multicolumn{2}{|c|}{ To what extent do you agree or disagree with the following statements? } \\
\hline Differences & $\begin{array}{l}\text { Differences in income in the United Kingdom [US] } \\
\text { are too large. }\end{array}$ & 5-point Likert \\
\hline Government & $\begin{array}{l}\text { It is the responsibility of the government to re- } \\
\text { duce the differences in income between people } \\
\text { with high incomes and those with low incomes. }\end{array}$ & 5-point Likert \\
\hline Desert & $\begin{array}{l}\text { Most of the time, people with high incomes de- } \\
\text { serve their high incomes. }\end{array}$ & 5-point Likert \\
\hline \multicolumn{3}{|l|}{ Socio-demographic } \\
\hline Gender & What is your gender? & Male / Female \\
\hline Age & What is your age? & 7-level Mult. Ch. \\
\hline Region & In which region / state do you currently reside? & $\begin{array}{l}\text { Multi Ch. (Eng- } \\
\text { land: } 4 \text { regions; } \\
\text { US: } 50 \text { states \& } \\
\text { DC) }\end{array}$ \\
\hline Education & $\begin{array}{l}\text { What is the highest level of education you have } \\
\text { completed or the highest degree you have re- } \\
\text { ceived? }\end{array}$ & 8-level Mult. Ch. \\
\hline Employment & What is your current employment status? & 8-entry Mult. Ch. \\
\hline Political party & $\begin{array}{l}\text { Which of these political parties do you consider } \\
\text { yourself closest to? }\end{array}$ & $\begin{array}{l}3 \text { main parties / } \\
\text { Other (to specify) } \\
\text { / None }\end{array}$ \\
\hline Political leaning & $\begin{array}{l}\text { On economic policy matters, where do you see } \\
\text { yourself on the left/right [liberal/conservative] } \\
\text { spectrum? }\end{array}$ & $\begin{array}{l}\text { Left / Centre / } \\
\text { Right }\end{array}$ \\
\hline Vote (only US) & $\begin{array}{l}\text { Who did you vote for in the } 2020 \text { Presidential Elec- } \\
\text { tion? }\end{array}$ & $\begin{array}{l}\text { Trump / Biden } \\
\text { / Other / Didn't } \\
\text { vote }\end{array}$ \\
\hline Income & $\begin{array}{l}\text { Would you say the total income, before taxes and } \\
\text { deductions, of all family members living in your } \\
\text { household in } 2019 \text { was...? }\end{array}$ & $\begin{array}{l}\text { Two chained } \\
\text { questions; in- } \\
\text { come in } £ 10000 \\
\text { brackets below } \\
£ 50000 \text {, in } £ 25 \\
000 \quad \text { brackets } \\
\text { above. }\end{array}$ \\
\hline
\end{tabular}

